\title{
Explaining the Short- and Long-Term IPO Anomalies in the US by R\&D
}

\author{
Re-Jin Guo, Baruch Lev, and Charles Shi ${ }^{*}$
}

\begin{abstract}
Financial scholars who research the initial underpricing and long-term underperformance of IPOs generally attribute these phenomena to information asymmetry and investors' misevaluations. Here, we identify, on a sample of 2,696 US IPOs issued during 19801995, a widespread source of information asymmetry and valuation uncertainty-the R\&D activities of issuers - and document that these activities significantly affect both the initial underpricing of IPOs (R\&D is positively correlated with underpricing) and their long-term performance ( $R \& D$ is positively related to long-term performance). Given the pervasiveness and constant growth of firms' R\&D activities in modern economies, our identification of R\&D as a major factor affecting IPO's performance contributes to the understanding of this important economic and capital market phenomenon.
\end{abstract}

Keywords: R\&D, IPO’s performance, information asymmetry, investor optimism

JEL classification: G12; G14; M40

\footnotetext{
* The authors are, respectively, at the University of Illinois at Chicago, New York University, and the University of California at Irvine. They thank Alexander Ljungqvist, Jim McKeown, Roni Michaely, Peter Pope, Andrew Stark, Ashley Wang, an anonymous referee, and participants at the 2003 American Accounting Association Meeting and the 2005 Journal of Business Finance and Accounting Conference for helpful comments.

Address for correspondence: Charles Shi, Paul Merage School of Business, University of California, Irvine, CA, USA.

email: cshi@uci.edu
} 


\section{Explaining the Short- and Long-Term IPO Anomalies by R\&D}

\section{Introduction}

Two persistent anomalies that characterize initial public offerings (IPOs) — the first-day underpricing and the long-term underperformance of certain IPOs—-have intrigued academics and practitioners over the past two decades and have generated considerable research aimed at explaining the apparent incongruities with rational asset pricing. While this research effort has provided numerous analytical advances and empirical insights, it is fair to say that both anomalies are not satisfactorily resolved. The initial underpricing - the first-day IPO price appreciation of close to 20\%, on average, during 1980-2001 (Ritter and Welch, 2002)—is still a puzzle, as is the long-term (3-5 years) performance of certain IPOs, which appears to lag considerably that of similar seasoned companies (e.g., Loughran and Ritter, 1995). Doubts have been raised, however, about the pervasiveness (only small nonventure-backed firms?) and uniqueness of the long-term underperformance of IPOs (Brav and Gompers, 1997). Thus, both the short- and long-term performance of IPOs obviously requires further illumination. ${ }^{1}$

Various theories have been developed to explain the first-day IPO underpricing, with most postulating the existence of information asymmetry between certain parties to the IPO process. ${ }^{2}$ Common to such models is the prediction that the extent of information asymmetry is positively

\footnotetext{
${ }^{1}$ While the bulk of the early IPO literature has focused on the US market, there is now a growing body of international studies that have confirmed the empirical regularities previously documented based on the US IPOs. That is, the initial underprcing phenomenon and poor long-run performance of IPOs exist in both industrialized and emerging markets (Loughran et al., 1994; Jenkinson and Ljungqvist, 2001; Ritter, 2003).

${ }^{2}$ For example, Baron's (1982) principal-agent model assumes that the underwriter (the agent) knows more about capital market conditions and potential investors than does the IPO issuer (the principle). The underpricing signaling models are built on the assumption that the issuer is better informed about firm value than are outside investors (e.g., Allen and Faulhaber, 1989). In contrast, adverse selection and "book-building" models assume that IPO investors know more than the issuer about market conditions and demand for IPO shares (Rock, 1986; Benveniste and Spindt, 1989). See Ritter and Welch (2002) for a review of theories of IPO underpricing.
} 
related to the first-day underpricing. However, despite this unambiguous theoretical prediction, the voluminous research on IPO underpricing rarely identifies the source of information asymmetry and uncertainty at IPO date. Rather, noisy proxies of information asymmetry, such as firm size, retained ownership, or underwriter reputation, are used in the empirical studies that associate information asymmetry and underpricing, thus clouding the empirical findings to an unknown extent. ${ }^{3}$

In this study, we identify a major and arguably the most important contributor to IPO uncertainty of science-based and technology issues - the research and development (R\&D) activities of issuers. R\&D expenditures are the intangible investment most extensively researched in economics, accounting and finance. The reason: R\&D expenditures have to be disclosed in corporate financial reports, whereas other intangible investments (e.g., employee training, brand enhancement, software development) are generally aggregated with other expense items. Data availability does wonders for research. The empirical $R \& D$ literature has substantiated two important phenomena related to our study: R\&D contributes to information asymmetry, and R\&D-intensive firms are often undervalued by investors. The former phenomenon—R\&D-related information asymmetry—is supported by studies such as Aboody and Lev (2000) documenting that insiders (managers, large block holders) of companies intensive in R\&D—presumably privy to proprietary information on the progress and potential of R\&D projects—-gain from trading in the stock of their firms substantially more than insiders in low $R \& D$ or no-R\&D companies. The latter phenomenon-R\&D-intensive companies are

\footnotetext{
${ }^{3}$ For example, in contrast to the negative association between IPO underpricing and underwriter reputation reported by Carter and Manaster (1990) and Carter et al. (1998), we do not find that underwriter reputation explains the cross-sectional variation in IPO underpricing (Table 4). In addition, although issue size is sometimes found to be negatively related to underpricing, other studies (e.g., Michaely and Shaw, 1994) report a positive relation of firm size to IPO underpricing. Such empirical inconsistencies might be due to the noisy proxies (e.g., underwriter reputation, firm size) of information asymmetry.
} 
undervalued by investors-is supported by numerous studies that examine the association between R\&D investment and subsequent stock returns in the US (Lev and Sougiannis, 1996; Chan et al., 2001; Penman and Zhang, 2002; Eberhart et al., 2004). ${ }^{4}$

Both the contribution of R\&D to information asymmetry and the systematic mispricing of the stocks of R\&D-intensive companies are at least partially attributed to inadequate disclosure of R\&D activities and their prospects in corporate financial reports. In particular, current US GAAP mandates the disclosure of the aggregate amount of $R \& D$ expenditures only. Consequently, no systematic information on the nature of R\&D activities (e.g., basic research vs. improvement in current technologies) or on the progress of R\&D projects (e.g., software development programs that passed successfully technological feasibility tests) is disclosed to investors, presumably due to concerns with revealing proprietary information to competitors. ${ }^{5}$ The absence of timely information on R\&D activities, and the relatively (to tangible assets) high uncertainty associated with $R \& D$ appear to explain the unique market-related attributes of $R \& D$ in the US (e.g., Eberhart et al., 2004).

The documented contribution of R\&D to information asymmetry and the capital market mispricing of R\&D-intensive companies are essential to our arguments in this study. Whereas the extensive IPO underpricing literature relates the underpricing primarily to information asymmetry, we focus on a major source of this asymmetry—R\&D activities—and document a strong association between these activities and IPO underpricing. This then leads us to the second phenomenon—mispricing of R\&D-intensive companies—which we examine in the long-

\footnotetext{
${ }^{4}$ An alternative explanation for the excess stock returns following $R \& D$ investment is that the existing asset pricing models may not fully control for the riskiness of R\&D-intensive firms. Chambers et al. (2002) provide some evidence consistent with the risk explanation. They, however, acknowledge that their results do not rule out the mispricing possibility.

${ }^{5}$ Add to this fact that in many countries, particularly in the European continent, there is not even a requirement to disclose R\&D expenditures, and the scope of information asymmetry and misevaluations becomes wider.
} 
term, post IPO performance section of our study. We thus incorporate in this paper the main documented phenomena concerning R\&D.

Our findings are indeed consistent with the conjectured relation between R\&D and IPO underpricing.. We show, on a sample of 2,696 US IPOs issued during 1980-1995, that the preIPO intensity of the issuer's $R \& D$ (the ratio of $R \& D$ expenditures to sales or to expected market value) is strongly and positively related to the first-day underpricing: The first-day returns to R\&D-intensive issuers are almost double the corresponding returns on IPOs without R\&D (8.7\% vs. $15.0 \%$ market-adjusted average returns (underpricing) for no-R\&D and high-R\&D IPOs, respectively). Thus, in a regression of first-day returns (underpricing) on various explanatory variables, R\&D intensity turns out to be a highly significant regressor, whereas underwriter reputation and venture capital backing-important regressors in previous research-are statistically insignificant.

The importance of identifying the source of information asymmetry at IPO, rather than relying on noisy proxies, is that, once identified, it is possible to guide the efforts of managers (via voluntary disclosure), investors (by concerted search into the nature and potential of R\&D), and capital market regulators to reduce information asymmetry and enhance market efficiency. We accordingly document the link between information disclosure about R\&D (reducing asymmetry) and IPO underpricing by comparing the underpricing associated with pharmaceutical and biotech IPOs_companies that uniformly disclose extensive information about the nature of R\&D (success of products under development and prospective outcomes)— with the underpricing of other R\&D-intensive issuers that disclose considerably less information on their R\&D activities. We find that pharmaceutical and biotech IPO underpricing, despite the generally high uncertainty associated with drug development, is substantially lower than the 
underpricing of other R\&D intensive issues. Thus, enhanced disclosure about the nature of $R \& D$ activities and prospective outcomes reduces information asymmetry and is thus rewarded by diminished underpricing.

From underpricing in the first day of the IPO, we turn to the long-term performance of IPOs and its association with the R\&D intensity of the issuers. Loughran and Ritter (1995) document that, on average, IPO stocks underperformed seasoned firms of the same size by approximately 7\% annually during a five-year period post IPO, suggesting that investors are overly optimistic about the prospects of firms at the time they go public. The general investor optimism at IPO, however, may be mitigated or even nonexistent for R\&D-intensive issues as a result of investors’ heightened concerns about the prospects of R\&D activities. Recent studies show that, for seasoned stocks, investors are slow to recognize the full extent of R\&D benefits, probably due to the considerable information asymmetry associated with R\&D (e.g., Chan et al., 2001; Eberhart et al., 2004). To the extent that investors' general optimism at IPO is offset by their tendency to under-react to the potential benefits of $R \& D$, we expect that $R \& D$-intensive IPOs will experience a lesser degree of underperformance in the long run than will no-R\&D IPOs. Thus, we expect the long-term performance of $R \& D$-intensive IPOs, benefiting from the resolution of $R \& D$ uncertainty at IPO, to be better than that of low- or no-R\&D IPOs. Indeed, we find that the longterm (three years post IPO) underperformance is a phenomenon restricted to non-R\&D IPOs. Furthermore, we document that high-R\&D IPOs outperform low-R\&D IPOs, which in turn outperform non-R\&D IPOs in the long run. Specifically, going long (investing) in high-R\&D, or in high- and low-R\&D IPOs, and short on no-R\&D IPOs, yields significant excess returns of 79\% annually during a three-year period post IPO. 
To enhance our long-term analysis, we provide direct evidence that the uncertainty and risk of R\&D mitigate investor optimism at IPO. We measure investor optimism as the difference between the consensus analyst forecast of long-term (typically five-year) earnings growth made within one year of IPO and the actual earnings growth over the corresponding period. We indeed find that the no-R\&D IPOs in our sample had a substantially higher level of investor optimism than did high-R\&D IPOs, consistent with our argument that R\&D-intensity exerts a dampening effect on investor sentiment.

Finally, we address the widely discussed question of "leaving money on the table" at IPO, namely, why do issuers underprice IPOs. We argue that R\&D-intensive issuers are more willing to forgo money at IPO than are no-R\&D issuers, because they expect to recoup the money left on the table by subsequent issues of seasoned stocks when the market realizes over time the positive outcomes of their R\&D. Consistent with this argument, we find that high-R\&D issuers indeed collect more post-IPO proceeds from seasoned stock offerings than do low- and no-R\&D issuers.

Our main contribution to the IPO research is the identification of an important and pervasive factor—R\&D activities—underlying various IPO-related anomalies; the short-term underpricing and the long-term underperformance of IPOs. In the process, we extend specific previous research findings, showing that R\&D intensity at IPO is a significant determinant of IPO underpricing after controlling for various frequently used proxies for information asymmetry, such as venture capital backing and underwriter reputation. We also show that the long-term underperformance of IPOs is a manifestation of excessive investor optimism of no-R\&D IPOs. In contrast, R\&D-intensive IPOs, less prone to investor optimism, do not exhibit the post-IPO underperformance. Thus, our issue-specific pre-IPO R\&D intensity measure (observable by IPO investors) reliably predicts both the initial underpricing and the long-term performance of IPOs. 
The rest of the paper is organized as follows. Section II presents the sample selection procedure, and Section III discusses the first-day underpricing results. Section IV investigates the long-term performance of IPOs, and Section V concludes the study.

\section{Sample Selection}

Our initial sample consists of 6,010 US initial public offerings (IPOs) derived from the New Issues Database of Securities Data Co. (SDC) for the 1980-1995 period. We wished to exclude from the analysis the abnormal years of 1999-2000 that were dominated by Internet IPOs and bubble prices. Recent studies suggest that information asymmetry is unlikely to be a major determinant of underpricing for Internet IPOs (Ritter and Welch, 2000). Therefore, exclusion of the Internet IPOs enables us to focus on the role of information asymmetry in IPO underpricing. ${ }^{6}$ Consistent with extant IPO literature, we excluded unit offerings, ADRs, offerings of foreign corporations (F-1 filings), REITs, mutual funds filings, filings of financial institutions (SIC code 6000-6999), and of services companies (SIC code >8100). To be included in the final sample, an IPO had to satisfy the following criteria: (1) an offer price of no less than $\$ 3$ per share, (2) the required price and accounting data available from CRSP and Compustat, and (3) relevant IPO data available from SDC. To eliminate the undue influence of outliers, we excluded from the sample offerings with first-day return (underpricing) of less than the $0.5^{\text {th }}$ or greater than $99.5^{\text {th }}$ percentile of the pooled observations (27 cases). The final sample includes 2,696 IPOs, and the sample selection process is summarized in Table 1.

Table 1 here

\footnotetext{
${ }^{6}$ Schrand and Verrecchia (2004) also excluded Internet firms from their main IPO sample due to the same consideration.
} 


\section{R\&D and the First-day IPO Underpricing}

We examine here whether the extent of IPO underpricing is positively related to the intensity of firms' $R \& D$ expenditures. The intensity of $R \& D$ is measured as the ratio of annual $R \& D$ expenditures to sales, and alternatively as $R \& D$ expenditures to the expected market value of the firm at issuance (the product of the midpoint of the offer price range proxying for expected offer price and the expected number of shares to be outstanding upon the IPO). We use the R\&D and sales figures for the last fiscal year before IPO (reported in the prospectus). Thus, our measures of R\&D intensity are observable by investors prior to IPO. Throughout the study, we consider three groups of firms: those without R\&D (no-R\&D IPOs), those with low R\&D intensity (below sample median of $R \& D$ intensity), and high $R \& D$ intensity IPOs (above median). As a robustness check, we also use continuous $R \& D$ intensity measures in place of R\&D portfolio dummies. Our findings are not sensitive to this manipulation.

\section{III.A. Underpricing Control Variables}

Since previous studies show that the extent of IPO underpricing is affected by various factors, we use these factors as control variables in our analysis:

(1) The natural log of issue proceeds (LNSIZE). Prior studies use the size of issue to control for the issuer's overall risk and issue uncertainty, since better established firms often make larger issues, and such sizable firms are generally less risky than those making smaller issues. This variable was found to be negatively associated with underpricing.

(2) The revision in offer price (P_AJT). Following Hanley (1993), we define P_AJT as the percentage change from the midpoint of the preliminary file range (the price range 
specified in the issuer's preliminary prospectus) to the actual offer price. Hanley (1993) documents a positive relationship between the revision in offer price and the extent of underpricing. ${ }^{7}$

(3) Underwriter reputation measure (CM). Prior research documents that IPOs underwritten by prestigious underwriters exhibit a lower level of underpricing than do IPOs with less prestigious underwriters (e.g., Beatty and Ritter, 1986; Carter and Manaster, 1990; Carter, Dark, and Singh, 1998). We use an updated, discrete underwriter reputation measure ranging from zero to nine, proposed by Carter and Manaster (1990), where a 9 (0) represents the most (least) prestigious underwriter. CM was found to be negatively associated with underpricing.

(4) The pre-offer demand (SECOND). This is the percentage of offering sold by pre-IPO shareholders. Hanley (1993) suggests that a strong (weak) pre-issue demand for an IPO will result in an upward (downward) adjustment in the number of shares offered by the existing shareholders. We include this variable in the analysis to capture the pre-issue demand, and hence expect it to be positively associated with the underpricing.

(5) The percentage ownership retained by insiders (INSIDE). Grinblatt and Hwang (1989) report that high-quality issuers differentiate themselves from low-quality firms by retaining a higher portion of the firms' shares after IPO. The percentage of shares that firm insiders retain can thus serve as a signal for firm quality. Grinblatt and Hwang (1989) report a positive association between the degree of underpricing and

\footnotetext{
${ }^{7}$ This relationship is termed the "partial-adjustment” phenomenon by Ibbotson et al., 1988). That is, the underwriter does not fully adjust the final offer price to the market value of the IPO on the first trading day. The underwriter presumably uses the underpriced IPO as a reward for the truthful revelation of investors' demand for the IPO (Benveniste and Spindt, 1989).
} 
the level of insiders' ownership (higher quality firms underprice more than do those of lower quality).

(6) Venture capital backing (VC). The presence of venture capitalists in the IPO firm is expected to signal issue quality (reduce the perceived uncertainty over firm value), and hence leads to a lower degree of underpricing (Megginson and Weiss, 1991). This variable takes the value of 1 for an issue backed by venture capitalists, and 0 otherwise.

\section{III.B. Underpricing and R\&D: Univariate Results}

Table 2 provides descriptive statistics of 2,696 sample IPOs. The distribution of the sample by year is summarized in Panel A. There is a wide variation in the number of IPOs over the sixteen-year period 1980-1995 with many of the observations clustering in the later five years. The proportion of IPOs with positive R\&D generally fluctuates over time within a range of 40 to 60 percent. To mitigate possible undue influence of larger numbers of positive-R\&D IPOs in certain years, we use yearly medians of R\&D intensity in portfolio formation so that in each sample year low- and high-R\&D portfolios have comparable numbers of IPOs. In addition, we include three time-period dummies $(1980-83,1984-89,1990-95)$ in regression analyses to control for the potential effect of time-series variation in sample composition and investor sentiment on IPO performance.

The industry composition of the sample is reported in Panel B of Table 2. Following Teoh et al. (1998), we classify the sample into 18 industries. Our sample IPOs are drawn from a wide variety of industry segments with computer hardware and software having the highest volume of IPOs. Although some industries like scientific instruments have greater proportions of its firms engaging in R\&D activities than do others such as retail, each of the sample industries has some 
of its firms investing in R\&D. Finally, among the total of 155 chemical products IPOs (SIC industry group 28), 93 of them are pharmaceutical and biotech firms (SIC of 283). This subset of IPOs is used later to analyze the effect of disclosure on underpricing.

Table 2, Panel C, provides descriptive statistics of the full sample, as well as for the three portfolios: firms without R\&D, firms with low R\&D (below sample median of R\&D-to-sales ratio), and firms with high (above-median) R\&D. The data in the table show that the IPO proceeds (issue size)—PROCEEDS—are lower at the mean for the high R\&D firms ( $\$ 28.55$ million) than for no or low R\&D firms ( $\$ 45.38$ and $\$ 41.95$ million, respectively), but the median proceeds are essentially the same for the three groups (\$23-24 million). ${ }^{8}$ A similar finding holds for R\&D deflated by the expected market values (EXPMV). The total sales of the IPO firms decrease at both the mean and median with the increase in R\&D intensity. The proportion of shares offered at the IPO by pre-IPO owners (SECOND) is higher for R\&D firms than for no$R \& D$ firms. Insiders thus sell more shares in the riskier R\&D firm, although not more in the high-R\&D issuers than in those with low R\&D. Underwriter reputation (CM) is not significantly different across R\&D portfolios. Venture capital backing (VC), however, is significantly different across R\&D portfolios: At the mean, $26 \%$ of the no-R\&D firms were backed by venture capital, compared with $44 \%$ and $75 \%$ for the low- and high-R\&D firms, respectively. Finally, the proportion of shares retained by insiders (INSIDE) does not vary much across R\&D groups.

\section{Table 2 here}

Table 3 provides univariate results of the IPO underpricing classified by intensity of R\&D. The underpricing is measured as the percentage change from the offer price to the first available

\footnotetext{
${ }^{8}$ The annual IPO proceeds are adjusted (deflated) to the 1995 price level, using the CPI index.
} 
first-day closing price on CRSP. The overall mean underpricing of our sample, in terms of raw returns, 10.8\%, compares well with the 9.68\% mean underpricing in Ritter and Welch (2002, Table 1, IPOs from 1980 to 1995). Corroborating our expectation, Table 3, Panel A, indicates that both the raw and market-adjusted underpricings increase monotonically with R\&D intensity (e.g., mean raw underpricing of $8.78 \%$ for no-R\&D firms vs. $11.17 \%$ and $15.04 \%$ for low- and high-R\&D firms, respectively). Table 3, Panel B, shows that the R\&D-related underpricing differentials existed in the three subperiods of the sample: 1980-1983, 1984-1989, and 19901995. The difference in underpricing between low- and high-R\&D issues in the 1990s (12.74\% vs. $19.0 \%$ ) was substantially larger than in the 1980 s.

Classification of the sample firms by size of IPO (Table 3, Panel C) indicates that the largest differences in underpricing across $\mathrm{R} \& \mathrm{D}$ groups occurs for the large (top quartile) issues ( $11.5 \%$ vs. $22.66 \%$ underpricing for the low- and high-R\&D issues), although the differences exist also in the medium-sized proceeds (second and third quartiles): 9.13\%, 11.46, and 14.78\% respectively, for the no-, low-, and high-R\&D groups. For small issues, the difference in underpricing exists only between the no-R\&D and R\&D IPOs.

Table 3, Panel D, reveals a somewhat counterintuitive result: The difference in the underpricing of low- and high-R\&D IPOs is larger for issues backed by high-reputation underwriters (11.94\% vs. $16.98 \%)$ than for issues backed by low-reputation underwriters (10.34\% vs. $12.49 \%)$. Moreover, for high-R\&D IPOs, the underpricing is larger for issues with high-reputation underwriters (16.98\%) than for low-reputation underwriters (12.49\%). If underwriters' reputation provides a quality signal (Carter and Manaster, 1990), the ranking of the underpricing differential should have been the reverse (i.e., smaller for high-reputation 
underwriters). In the multivariate analysis (see Section III.C), underwriter reputation is insignificant.

When the sample is classified by VC backing (Table 3, Panel E), the R\&D-related underpricing (low vs. high R\&D) differential is smaller for VC-backed issues $(12.45 \%$ vs. 14.97\%) than for non-VC-backed issues (10.10\% vs. $15.07 \%)$, but the total sample underpricing is higher for VC-backed issues than for non-backed issues. This appears to be the result of the high correlation (Table 2) between VC backing and R\&D intensity. The multivariate results presented below (Table 4) resolve this issue.

\section{Table 3 here}

Summarizing, the univariate analysis indicates that the extent of IPO first-day underpricing is positively related to the $R \& D$ intensity of the issuer. The finding holds for the overall sample period as well as for various subperiods. Furthermore, this finding holds when we keep constant issue size, underwriter reputation, or venture capital backing. R\&D thus appears as major source of uncertainty and information asymmetry reflected in the IPO underpricing.

\section{III.C. Underpricing and R\&D: Multivariate Analysis}

Here we bring together the three R\&D sample classifications and the underpricing control variables in a multivariate regression analysis. ${ }^{9} \quad$ The dependent variable is the difference between the percentage first-day underpricing and the corresponding NYSE/AMEX/NASDAQ value-weighted market index return, namely the abnormal underpricing. The three R\&D groups

\footnotetext{
${ }^{9}$ Three time-period dummies (1980-83, 1984-89, 1990-95) are also included in the regressions (but not tabulated) to control for time-series effects. The findings are robust with alternative sets of time-period dummies such as four equal length time dummies with each representing four consecutive years.
} 
(no-, low-, and high-R\&D) are represented by dummy variables, D1 through D3, along with the underpricing control variables. Panel A of Table 4 reports estimates from three regression models. Model (1) includes the control variables only. Estimates generally conform with previous findings: Issue size (PROCEEDS) is negatively associated with underpricing, and the price revision (from midpoint of the offer price range to the actual offer price) is positively related to underpricing; both are statistically significant. The presence of VC backing has a positive coefficient in Model (1), contrary to previous findings. ${ }^{10}$ This is probably due to the fact that $77 \%$ of the high-R\&D firms (having the largest underpricing) had VC backing, compared with $22 \%$ and $44 \%$ for no-R\&D and low-R\&D firms, respectively (Panel C of Table 2). The positive coefficient of VC in Model (1) appears, therefore, to be the result of the omission of a correlated variable. Indeed, the introduction of the R\&D variables into the regression (models 2 and 3) renders the VC coefficient statistically insignificant. The quantity INSIDE — the ownership portion retained by insiders—-has the hypothesized positive coefficient in Model (1).

Models (2) and (3) in Panel A of Table 4 introduce the three R\&D group dummies. Whether firms are classified into low- and high-R\&D by the sales intensity (R\&D-to-sales ratio), or by expected market value intensity (models 2 and 3, respectively), the estimated coefficients of the three R\&D groups conform with our expectation: They are statistically significant and monotonically increasing from D1 to D3. The pair-wise significance tests (at the bottom of Panel A) indicate that the differences between coefficients are generally statistically significant.

\footnotetext{
${ }^{10}$ Early studies documenting the negative association of venture capital backing with IPO underpricing (Megginson and Weiss, 1991) do not control for many other IPO determinants (such as role of underwriters) and hence should be interpreted with caution. Indeed, recent research (e.g., Hoberg and Seyhun, 2005) finds that venture capitalists and lead underwriters collaborate in the IPO process, and that after taking underwriters into account, the impact of venture capitalists on underpricing is mixed and varies with firm characteristics such as size.
} 
Compared with previous IPO research, Table 4 indicates that the R\&D effect is distinct from the VC effect on underpricing: The R\&D coefficients in models (2) and (3) are significant when VC backing is accounted for. In fact, the R\&D variable subsumes the VC information. Most other control variables, with the notable exception of underwriter reputation, CM, remain significant with the R\&D dummies.

One primary advantage of using $R \& D$ dummies is to avoid the linear parameterization of regressions (Teoh et al., 1998). This is important because the effect of R\&D activities on stock performance is unlikely to be uniform across firms given large differences in R\&D intensity level and in the nature of R\&D activities (e.g., software development vs. drug research). Nonetheless, categorical variables are not without limitations. For example, they do not reflect R\&D information as fully as continuous variables. Categorical variables may also capture some unknown sector effect. To assess the robustness of our findings, we use in regressions continuous R\&D intensity variables directly. The results are reported in Panel B, Table 4. The coefficients of alternative R\&D intensity measures (LOGRD_SALES and LOGRD_EXPMV) are positive and significant at the conventional levels. The control variables have coefficients comparable to those in Panel A in both magnitude and significance levels.

\section{Table 4 here}

Our analyses, consistent with the extant $R \& D$ studies, have treated $R \& D$ as an exogenous variable. To the extent that firms may take into account the R\&D effect on IPO pricing when they make investment decisions, there is a potential endogenous bias in the estimates of R\&D coefficients. To address the simultaneity issue, we adopt the instrumental variable method in a two-stage least squares regression. Similar to Lev and Sougiannis (1996), we choose as the 
instrument for issuer i’s R\&D intensity (relative to sales and expected market value, respectively) the average of $R \& D$ intensity of all sample IPOs in its 1-digit SIC code. In the first stage, we regress the issuer's $R \& D$ on its industry average $R \& D$. We then estimate Panel $B$ of Table 4 by substituting the predicted value of $R \& D$ intensity from the first stage regression for its actual value (the results are not tabulated). The coefficients of R\&D over sales and R\&D over expected market value are 0.44 and 1.83 , respectively. They are significant at the one percent level.

Taken together, our results are robust with respect to the choice of R\&D constructs, and they are not subject to simultaneity bias. ${ }^{11}$ In the interest of brevity, we report subsequent analyses using three R\&D groups based on actual R\&D values.

To provide additional insight, Table 5 presents regression estimates for a classification of R\&D firms to low and high groups by the annual change in $R \& D$, rather than the level of $R \& D$ used in the analysis thus far. It seems reasonable that the larger the increase in R\&D intensity, the greater will be the extent of information asymmetry reflected in the underpricing. Ideally, the change in $R \& D$ expenditures should be calculated from pre-issue data, to be observable by IPO investors. However, Compustat reports R\&D observations for two years prior to IPO for only 135 issuers. We, therefore, measure the change in R\&D from the year before IPO to the one subsequent to it, which strictly speaking is not observable at the IPO. However, the postissue $R \& D$ budgets (plans) are typically made prior to IPO, and this information may have been conveyed to the market either via SEC filings, and/or by direct communication with major prospective investors during road shows. Keeping this observability caveat in mind, regression estimates in Table 5 ( $R \& D$ change) for the R\&D dummies closely resemble those in Table 4

\footnotetext{
${ }^{11}$ Wherever applicable, we replicate other main regressions using continuous R\&D variables and/or the instrumental variable approach, and obtain qualitatively similar results.
} 
(R\&D level). Thus, both the level and change of R\&D are positively associated with the extent of IPO underpricing.

\section{Table 5 here}

Information Disclosure and IPO Underpricing

Underpricing is costly to issuers, and therefore they can be expected to attempt to reduce the cost. Ceteris paribus, expanded disclosures, if credible and not overly competitively harmful, would reduce information asymmetry and hence the IPO underpricing. Under current U.S. GAAP, R\&D expenditures are expensed as incurred and no information disclosure is required beyond the total amount of R\&D. Accordingly, R\&D-intensive IPOs generally do not disclose relevant information about their $\mathrm{R} \& \mathrm{D}$ activities in financial reports, presumably due to concerns of imparting crucial information to competitors. Exceptions include pharmaceutical and biotech companies, which uniformly disclose extensive information on product development and other R\&D attributes (e.g., patent protection) in the IPO prospectus (Guo et al., 2004). There are 93 pharmaceutical and biotech IPOs in our sample. All of them belong to the high-RD portfolio, which consists of 633 IPOs in total (see Table 2). To assess the incremental effect of information disclosure on IPO underpricing, it is important that we hold constant R\&D investment which by itself changes information environment in the IPO market. We, therefore, expect the underpricing of pharmaceutical and biotech IPOs (with the expanded disclosures) to be lower than the other high-R\&D IPOs. We empirically examine this conjecture by comparing the underpricing of pharmaceutical and biotech IPOs with that of the other high-R\&D IPOs, controlling for IPO underpricing determinants. The regression results are summarized in Table 6. The negative coefficient of the interaction variable DRUG*D3 indicates that the underpricing 
level of pharmaceutical and biotech IPOs is 5.64\% lower, on average, than that of the other highR\&D IPOs, despite the higher-than-average risk of the basic, next generation research conducted by the former. ${ }^{12}$ The difference is statistically significant at the $1 \%$ level. Thus, enhanced information disclosure about R\&D decreases the underpricing.

\section{Table 6 here}

\section{III.D. Recouping Money Left on the Table}

We conclude the underpricing analysis by examining the oft-raised question of "leaving money on the table” at IPO. If R\&D intensity increases underpricing (i.e., the loss to original owners), why do many issuers spend substantial resources on R\&D prior to IPO? Alternatively, why don’t all R\&D-intensive issuers disclose extensive information about the nature and prospective outcomes of $\mathrm{R} \& \mathrm{D}$, as practiced by pharmaceutical and biotech companies, to mitigate the underpricing? We conjecture that issuers spend heavily on R\&D and often restrict disclosure (usually to avoid benefiting competitors), thereby leaving substantial money on the table through underpricing, because they are confident that their R\&D efforts will pay off in the future, allowing them to recoup the loss of excess underpricing through higher proceeds from subsequent seasoned offerings. To be sure, issuers’ confidence in the prospects of R\&D must be, on average, higher than investors'. This makes sense, given the considerable information asymmetry associated with R\&D: Issuers know considerably more than do outsiders about the specification of products under development, results of product feasibility tests, and marketing prospects (e.g., Aboody and Lev, 2000).

\footnotetext{
${ }^{12}$ We do not make prediction for the underpricing level of the pharmaceutical IPOs relative to that of no- or lowR\&D IPOs, as differing degrees of R\&D intensity across these portfolios confound their relations. As indicated in Table 6, the coefficient of the pharmaceutical group is equal to $3.4(9.04-5,64)$, which is smaller than the coefficient of no-R\&D (D1) and low-R\&D (D2) groups. However, neither of these differences is statistically significant.
} 
To examine the "money left on the table" issue in relation to $\mathrm{R} \& \mathrm{D}$, we compare the post-IPO proceeds from seasoned stock offerings of the no-, low-, and high-R\&D portfolios in our sample. In line with other IPO studies, we limit re-issuing activities to a window of three years after IPO. Nominal proceeds are converted to 1995 real dollars using the CPI index. We measure the IPOs' subsequent re-issuing activities by total issue proceeds of equity offers relative to the IPO proceeds. Figure 1 portrays the cumulative equity proceeds for the three portfolios. Consistent with our hypothesis, the order of proceeds is: highest for high-R\&D, intermediate for low-R\&D, and lowest for no-R\&D. Thus, R\&D-intensive issuers recoup at least part of the underpricing money left on the table by subsequent stock issues when investors recognize the positive outcomes of R\&D.

Figure 1 here

Summarizing, the various tests (univariate and multivariate) conducted on the IPO underpricing in our sample consistently point at a strong and positive association between the extent of underpricing and the pre-issue R\&D intensity of the firm. The multivariate analysis indicates that the $R \& D$ factor we focus on is unique, not just proxying for factors affecting underpricing, since it is significant in the presence of these factors. Expanded disclosure of R\&D-related information mitigates the extent of initial underpricing, and issuers are willing to sustain the higher-than-average underpricing related to R\&D because they recoup the money left on the table by post-IPO equity offering. 


\section{IV. $\underline{R} \& D$ and the Long-Term Performance of IPOs}

We now turn to the long-term performance of IPOs. The primary objective of this analysis is to examine whether issuers' pre-IPO R\&D intensity is associated with (explains) the long-term performance of IPOs. The evidence on the long-term underperformance of certain IPOs suggests excessive investor optimism at IPO. To the extent that R\&D-intensive IPOs are less prone to investor optimism than no- or low-R\&D IPOs, due to investors' concerns with the prospects of R\&D (see evidence reported in Section IV.C), we expect that high-R\&D IPOs do not exhibit the relatively poor long-term performance observed for IPOs in general, and that high-R\&D IPOs outperform no- and low-R\&D IPOs in the long run.

\section{IV.A. Related Literature}

Various studies have documented that IPOs underperform over the long term (Ritter, 1991; Loughran and Ritter, 1995; Mikkelson et al., 1997). For example, Loughran and Ritter (1995) report, for IPOs issued during 1970-1990, that the mean annual returns during the five years after issue was only $5 \%$, compared with a $12 \%$ return generated by non-IPO firms with similar market capitalization. The authors contend that IPO investors tend to be overly optimistic about the prospects of new equity issues, leading to inflated post-IPO prices and consequently to poor long-term performance. ${ }^{13}$

Subsequent studies indicate that the IPO underperformance is largely restricted to nonventure-backed IPOs. Brav and Gompers (1997) report that, in the long run, venture-backed IPOs do not underperform comparable benchmarks, and Carter et al. (1998) document that the long-term performance of IPOs is positively associated with underwriter reputation. These 
findings suggest that IPOs backed by venture capitalists or issued by reputable underwriters are less susceptible to investor optimism than are other IPOs, presumably because neither venture capitalists nor reputable investment bankers want to be associated with failures of IPOs. They are therefore less willing to hype or overprice new issues. Teoh et al. (1998) report that IPO underperformance is positively related to the size of the firm's "discretionary accruals" in the year of IPO, suggesting that earnings management by IPO issuers is a possible source of investor optimism. $^{14}$

Another strand of research related to our analysis is the stock market valuation of $R \& D$ expenditures. Recent work documents that investors systematically undervalue the future benefits of R\&D, presumably due to the high degree of uncertainty and information asymmetry associated with R\&D (e.g., Chan et al., 2001; Eberhart et al., 2004). Consequently, R\&Dintensive stocks experience significant positive long-term abnormal returns, as the market eventually recognizes the benefits of $R \& D$. Thus, when $R \& D$ is considered, the long-term performance of R\&D-intensive IPOs can reflect two offsetting forces: investors' general optimism about IPO prospects, which drives down performance, and their skepticism about R\&D outcomes, which drives up long-term performance. We now examine this conjecture.

\section{IV.B. The Long-Term Performance of IPOs}

The examination of the long-term performance of IPOs requires an appropriate measure for expected long-run returns, an issue much debated in the asset pricing literature (e.g., Fama, 1998;

\footnotetext{
${ }^{13}$ Other explanations for the long-term underperformance include constraints on shorting IPOs (Miller, 1977) and the psychological prospect theory (Ma and Shen, 2004).

${ }^{14}$ Accounting accruals (e.g., depreciation, provision for bad debt) constitute the difference between reported earnings and cash flows. Discretionary accruals are those that are largely controlled by managers, such as pension and warranties expense estimates. Accruals have been shown to be a major means for earnings manipulation by management (e.g., Sloan, 1996).
} 
Mitchell and Stafford, 2000). Recent studies that examine long-term IPO performance (Brav and Gompers, 1997; Teho et al., 1998; Ritter and Welch, 2002) and subsequent seasoned stock returns following R\&D investments (Chan et al., 2001; Al-Horani et al., 2003; Eberhart et al., 2004) employ time-series multi-factor models (Fama and French, 1993; Carhart, 1997) and cross-sectional regressions (Fama and MacBeth, 1973). The time-series models estimate factor loadings and evaluate the overall fit of a factor pricing model in a simultaneous fashion. They therefore alleviate the errors-in-variables problem typically present in separate estimation of risk measures. On the other hand, the cross-sectional regressions use directly the firm's characteristics such as size and book-to-market ratios, which are considered by Daniel and Titman (1997) as better predictors of returns than the Fama-French factors. In addition, they can accommodate additional control variables, which are useful for assessing potential missing risk factors and robustness of analyses. Given the complementary nature of the two approaches, we conduct both time series and cross-sectional regressions.

\section{IV.B.1. Time Series Regressions}

We examine the long-term performance of IPOs, conditional on their pre-IPO R\&D intensity. Following recent work that examines the long-term performance of IPOs (Brav et al., 2000; Eberhart et al., 2004), we use a four factor calendar time-series regression approach in this test.

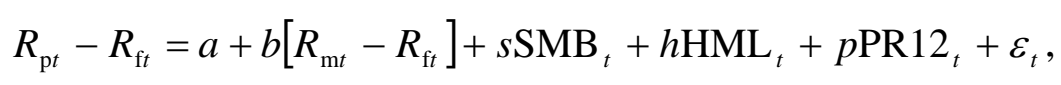

where $R_{\mathrm{pt}}$ is the equally-weighted return on the portfolio of IPO firms in calendar month $t ; R_{\mathrm{m} t}$ is the return on the value-weighted index of NYSE, AMEX, and NASDAQ stocks in month $t ; R_{\mathrm{ft}}$ is the beginning-of-month three-month T-bill yield in month $t$; $\mathrm{SMB}_{t}$ is the difference between the 
return on small firms and the return on large firms in month $t$ (size effect); $\mathrm{HML}_{t}$ is the difference between the return on high book-to-market stocks and the return on low book-tomarket stocks in month $t$ (book-to-market effect) (Fama and French, 1993), and PR12 is the difference between the return on high-momentum stocks and the return on low-momentum stocks (Carhart, 1997). The quantities $a, b, s, h$, and $p$ are regression coefficients for their respective independent variables. The focus of our analysis is on the regression intercept which estimates abnormal stock returns, given the four risk factors. ${ }^{15}$ Returns on IPO firms are included in the portfolio for the period from the 7th until the 42nd month subsequent to the month of IPO, during the period from April 1981 to December 1998 . $^{16}$

Regression estimates for the full sample as well as for the no-, low- and high- R\&D portfolios are presented in Table 7, Panel A, indicating that the intercept (excess returns) is negative but insignificant for the full sample of IPOs, consistent with Brav et al. (2000). Results for the three subsamples of IPOs indicate a systematic variation in the intercept estimates. We find that only the no-R\&D portfolio exhibits significant negative excess return, with the estimated intercept equal to 50 basis points return per month (translating to an annual negative excess return of approximately 6\%). In contrast, the estimated excess returns on IPOs with R\&D are higher: roughly zero and $0.27 \%$, for the low- and high-R\&D portfolios, respectively. Neither of these returns, however, is significantly different from zero. The intercept estimates are similar

\footnotetext{
${ }^{15}$ We obtain qualitatively similar results when the Fama-French three-factor model is used. To the extent that the existing multi-factor asset pricing models do not fully capture the riskiness of R\&D (Chambers et al., 2002; AlHorani et al., 2003), the intercept from the time-series model may reflect in part a manifestation of the R\&D risk. To alleviate the risk concern, we include $\mathrm{R} \& \mathrm{D}$ variables directly in subsequent Fama-MacBeth panel regressions. In addition, we compare across different portfolios operating performances which are not susceptible to the deficiencies of the asset pricing models.

${ }^{16}$ Investor sentiment is likely to be higher during the lockup period (first 6 months after the IPO), due to short sale constraints that prevent the beliefs of pessimistic investors from being incorporated in the price. To avoid the influence of the shorting constraints, our first portfolio return starts from the $7^{\text {th }}$ month after IPO. Our conclusions, however, are not sensitive to the selection of starting month.
} 
when the portfolios are sorted by the ratio of R\&D to expected market capitalization (Table 7 , Panel B).

Table 7 here

In Table 8, we report an estimated difference in intercepts between the no- and high- R\&D portfolios and the associated $t$-statistics from a time series regression of a zero-investment portfolio. The zero-investment portfolio consists of going long on the high-R\&D IPOs, while shorting the no-R\&D IPOs, and rebalancing monthly. As our result indicates, the estimated excess return from such a portfolio in a four-factor model is 76 basis points per month, suggesting that IPO firms with no R\&D have significantly poorer post-IPO returns than those with high pre-IPO R\&D. The differential performance persists when the zero-investment portfolio consists of going long on both the high- and low-R\&D firms, while shorting the no$\mathrm{R} \& \mathrm{D}$ firms (64 basis points per month). This also holds when the three portfolios are sorted by the ratio of R\&D to expected market capitalization (Panel B) instead of to sales (77 basis points per month).

Table 8 here

\section{IV.B.2. Fama-MacBeth Panel Regressions}

In this subsection, we adopt the Fama-MacBeth (1973) panel regression methodology in examining the differential returns across IPO firms. In each month during the period from April 1981 to December 1998, we estimate a cross-sectional regression on the universe of NYSE, AMEX, and NASDAQ firms for which the book value of equity is available from COMPUSTAT and monthly stock returns data is available from CRSP. As in Teoh et al. (1998), 
we include in the Fama-MacBeth regressions seasoned stocks as a control sample. In each month, returns for all firms with available data are regressed on size and the book-to-market ratio, the three $R \& D$ dummy variables (D1, D2, and D3) for no-R\&D, low-R\&D, and high-R\&D IPOs, as well as the updated Carter-Manaster underwriter reputation measure and a VC-backing indicator:

$$
\begin{aligned}
r_{i t}=a_{0}+a_{1} \operatorname{lnMV}_{i t}+a_{2} \ln (\mathrm{BV} / \mathrm{MV})_{i t} & +\operatorname{ISSUE}_{i t}\left(a_{3} \mathrm{D} 1+a_{4} \mathrm{D} 2+a_{5} \mathrm{D} 3+a_{6} \ln (1+\mathrm{CM})\right. \\
& \left.+a_{7} \mathrm{VC}\right)+\varepsilon_{i t},
\end{aligned}
$$

where the independent variables $\mathrm{MV}$ and $\mathrm{BV}$ are the market and book values (in millions of dollars) of equity. ISSUE is an IPO indicator variable equal to one for an IPO in our sample and zero for a seasoned stock. An issue is considered as an IPO if it falls in the three-year period from the $3^{\text {rd }}$ to $38^{\text {th }}$ month after the IPO. In addition, the cross-product terms of the IPO indicator variable with underwriter rankings, as well as venture-backing dummy, is included to control for the previously reported effects of those financial intermediaries in the new-issue market (Brav and Gompers, 1997; Carter et al., 1998).

Table 9 presents the regression results, where each column summarizes the results of 213 monthly regressions. From the distribution of 213 estimated coefficients, we calculate the mean estimated coefficients, the corresponding t-statistics, and the percentage of the coefficient estimates that are positive. Results from Model 1 show that the mean estimated coefficient on the no-R\&D indicator (D1) is negative and highly significant (at the $1 \%$ level), whereas the mean estimated coefficient on the high-R\&D indicator (D3) is not significantly different from zero. Inclusion of the VC backing and underwriter reputation variables does not appreciably affect the 
R\&D coefficients, and the reputation coefficient is positive and significant. Results are similar when the three portfolios (D1, D2, and D3) are instead sorted by the ratio of R\&D investment over expected market capitalization. This indicates a positive correlation between pre-IPO R\&D intensity and subsequent stock returns, which corroborates our findings in previous subsections. ${ }^{17}$

\section{Table 9 here}

Summarizing, the long-term portfolio tests confirm our conjecture that the performance of IPOs intensively engaged in R\&D is substantially better than that of no-R\&D IPOs. ${ }^{18}$

\section{IV.C. Is Investors' Optimism Related to R\&D?}

Our long-term portfolio estimates presented above suggest that investors' general optimism about IPO prospects (the conjectured explanation for the long-term underperformance of IPOs) is mitigated by concerns about R\&D outcomes. We conclude the long-term analysis by providing direct evidence on this issue, namely on the association between R\&D and investors' expectations as reflected by analyst earnings forecasts. Specifically, we measure investor optimism as the difference between analysts' consensus forecast of the issuer's long-term (typically five-year) earnings growth made within one year after IPO and the realized percentage earnings growth over the five years post IPO. To the extent that the high uncertainty and risk of

\footnotetext{
${ }^{17}$ When we replace the three $R \& D$ dummies with continuous $R \& D$ intensity variables (R\&D over sales and R\&D over market value), the coefficients on the $R \& D$ variables are positive and significant at the conventional levels.

${ }^{18}$ We also compare operating performance of the three (no, low and high-R\&D) portfolios. Specifically, we calculate two commonly used profitability measures—return on equity (ROE) and return on total assets (ROA) - for each sample IPO over a five-year period beginning one year before the IPO, through the IPO year and three subsequent years. In each event year, we calculate the medians of ROA and ROE for the three portfolios separately. We find that in each of the post-IPO three years firms' profitability increased monotonically with R\&D intensity and the profitability differences between firms with high R\&D intensity and firms without R\&D is positive and highly statistically significant. This evidence lends support to our argument that high-R\&D IPOs outperform the other IPOs in the long run.
} 
R\&D mitigate investor sentiment, we expect that investor optimism would be negatively correlated with pre-IPO R\&D intensity.

The data on analysts' long-term earnings forecasts and the five-year post-IPO historical earnings growth are obtained from Institutional Brokers Estimate System (I/B/E/S). The consensus forecast is computed as the median of the individual analysts following the firm. Since many of our sample IPOs do not have I/B/E/S earnings forecasts, the sample with the required forecasts data is smaller than that in the above analyses, consisting of 1,153 IPOs (out of 2,696 sample IPOs).

Table 10, Panel A, reports the mean values of the investor optimism measure (difference between earnings forecast and realization) corresponding to the three R\&D portfolios. Indeed, the average level of investor optimism is the highest for the non-R\&D portfolio followed by the low- and high-R\&D portfolios. The mean difference between the non-R\&D and high-R\&D portfolios is statistically significant. To control for the potential impact of firm size and industry on long-term earnings forecasts, we perform a multivariate analysis, regressing our measure of investor optimism on R\&D portfolio dummies (D1-D3), the logarithm of market value of equity, one-digit industry dummies, and the time period dummies. Regression results are summarized in Table 10, Panel B and indicate that the coefficient of the high R\&D portfolio is significantly lower than the coefficients of the no- or low-R\&D portfolios, consistent with the univariate results of Panel A. Taken together, we provide evidence that R\&D-intensive IPOs are less prone to investor optimism than are other IPOs, apparently affecting long-term performance. ${ }^{19}$

\footnotetext{
${ }^{19}$ This conclusion should be interpreted with caution. Our proxy for investor sentiment is based on ex post data that could mechanically correlate with long-term IPO returns.
} 


\section{Conclusions}

Finance scholars have extensively researched the substantial initial underpricing of IPOsroughly 20\%, on average-and the long-term underperformance of certain types of IPOs. Most models and hypotheses explain these anomalies by information asymmetries and investors' misevaluations, but do not identify the specific sources of these information asymmetries. In this study, we identify a major source of the information asymmetries affecting IPO short- and longterm performance: the R\&D activities of issuers. We document that the issuers’ R\&D intensity is positively associated with the initial IPO underpricing and also positively associated with the long-term performance of IPOs, thus singling out R\&D as a major contributor to both the shortand long-term performance of IPOs. We also provide evidence that R\&D intensity affects analysts’ forecasts of IPO long-term earnings.

The importance of identifying R\&D as a major factor that affects both the short- and longterm performance of IPOs is that it provides both investors and managers with actionable knowledge. Investors can increase their information search about the nature of the $R \& D$ conducted by IPO issuers, such as examining the intellectual property protection of $R \& D$ outcomes (patents) and the results of feasibility tests, thereby reducing information asymmetry. Managers can achieve the same effect with enhanced information disclosure. Market efficiency and investor welfare will improve with such information enhancement about the R\&D activities of IPOs.

Although we focus on the US IPOs, our findings should be of interest to international audience. International investors who seek to profit from the US equity market may benefit from taking into account ex ante observable $R \& D$ measures when they build their portfolios and trading strategies. Further, given substantial differences in legal, accounting, cultural, and 
regulatory frameworks across countries, it is an empirical question of whether the results in this study can be generalized to other countries. Future research exploring international dimension could be fruitful. 


\section{$\underline{\text { References }}$}

Aboody, D., and B. Lev (2000), 'Information Asymmetry, R\&D and Insider Gains', Journal of Finance, Vol.55, pp. 2747-2766.

Al-Horani, A., P. F. Hope and A. W. Stark (2003), 'Research and Development Activity and Expected Returns in the United Kingdom’, European Finance Review, Vol. 7: pp. 27-46.

Allen, F., and G. Faulhaber (1989), 'Signaling by Underpricing in the IPO Market', Journal of Financial Economics, Vol.23, pp. 303-324.

Baron, D. (1982), 'A Model of the Demand for Investment Banking Advising and Distribution Services for New Issues’, Journal of Finance, Vol.37, pp. 955-976.

Barth, M., and R. Kasznik (1999), 'Share Repurchases and Intangible Assets', Journal of Accounting and Economics, Vol.28, pp. 211-241.

Beatty, R., and J. Ritter (1986), 'Investment Banking, Reputation, and the Underpricing of Initial Public Offerings’, Journal of Financial Economics, Vol.15, pp. 213-232.

Benveniste, L., and P. Spindt (1989), 'How Investment Bankers Determine the Offer Price and Allocation of New Issues’, Journal of Financial Economics, Vol.24, pp. 343-361.

Brav, A., C. Geczy, and P.A. Gompers (2000), 'Is the Abnormal Return Following Equity Issuances Anomalous?’, Journal of Financial Economics, Vol.56, pp. 209-249.

Brav, A., and P. Gompers (1997), 'Myth or Reality? The Long-run Underperformance of Initial Public Offerings: Evidence from Venture and Nonventure Capital-backed Companies', Journal of Finance, Vol.52, pp. 1791-1821.

Carhart, M. (1997), 'On Performance in Mutual Fund Performance’, Journal of Finance, Vol. 52, pp. 57-82.

Carter, R., F. Dark, and A. Singh (1998), 'Underwriter Reputation, Initial Returns, and the Longrun Performance of IPO Stocks’, Journal of Finance, Vol.53, pp. 285-311.

Carter, R., and S. Manaster (1990), 'Initial Public Offerings and Underwriter Reputation', Journal of Finance, Vol.45, pp. 1045-1068.

Chambers, D., R. Jennings, and R. B. Thompson (2002), 'Excess Returns to R\&D-Intensive Firms', Review of Accounting Studies, Vol. 7, pp. 133-158.

Chan, K., J. Lakonishok, and T. Sougiannis (2001), 'The Stock Market Valuation of Research and Development Expenditure', Journal of Finance, Vol.56, pp. 2431-2456. 
Daniel, K., and S. Titman (1997), 'Evidence on the Characteristics of Cross Sectional Variation in Stock Returns', Journal of Finance, Vol.52(1), pp. 1-33.

Eberhart, A. C., W. F. Maxwell, and A. Siddique (2004), 'An Examination of Long-term Abnormal Stock Returns and Operating Performance Following R\&D Increases', Journal of Finance, Vol. 59, pp. 623-650.

Fama, E. F.(1998), 'Market Efficiency, Long-Term Returns, and Behavioral Finance', Journal of Financial Economics, Vol. 49, pp. 283-306.

Fama, E. F; K.R. French(1993), 'Common Risk Factors in the Returns on Stocks and Bonds', Journal of Financial Economics, Vol.33(1), pp. 3-56.

Fama, E.F., and J.D. Macbeth (1973), 'Risk, Return and Equilibrium—Empirical Tests', Journal of Political Economy, Vol.81(3), pp. 607-636.

Grinblatt, M., and C. Hwang (1989), 'Signalling and the Pricing of New Issues', Journal of Finance, Vol.44, pp. 393-420.

Guo, R., B. Lev, and N. Zhou (2004), 'Competitive Costs of Disclosure by Biotech IPOs', Journal of Accounting Research, Vol.42, pp. 319-355.

Hanley, K. (1993), 'The Underpricing of Initial Public Offerings and the Partial Adjustment Phenomenon', Journal of Financial Economics, Vol.34, pp. 231-250.

Hoberg, G., and H. N. Seyhun (2005), 'Do Underwriters Collaborate with Venture Capitalists in IPOs? Implications and Evidence’, Working paper (University of Michigan).

Ibbotson, R., J. Sindelar, and J. Ritter (1988), 'Initial Public Offerings', Journal of Applied Corporate Finance, Vol.1, pp. 37-45.

Jenkinson, T. and A. Ljungqvist (2001), Going Public (Oxford University Press).

Lev, B., and T. Sougiannis (1996), 'The Capitalization, Amortization and Value-Relevance of R\&D', Journal of Accounting and Economics, Vol. 21, 107-138.

Loughran, T., and J. Ritter (1995), 'The New Issues Puzzle', Journal of Finance, Vol.51, pp. 2352.

Loughran, T., J. Ritter and K. Rydqvist (1994), 'Initial Public Offerings: International Insights', Pacific-Basin Finance Journal, Vol. 2, pp. 165-199.

Ma, T, and Y. Shen (2004), 'Prospect Theory, and the Long-run Performance of IPO Stocks', Working paper (University of Utah). 
Megginson, W., and K. Weiss (1991), 'Venture Capitalist Certification in Initial Public Offerings', Journal of Finance, Vol.46, pp. 879-903.

Michaely, R, and W. Shaw (1994), 'The Pricing of Initial Public Offering: Tests of Adverse Selection and Signaling Theories’, Review of Financial Studies, Vol.7, pp. 279-319.

Mikkelson, W., M. Partch, and K. Shah (1997), 'Ownership and Operating Performance of Companies that Go Public’, Journal of Financial Economics, Vol.44, pp. 281-307.

Miller, E., M. (1977), 'Risk, Uncertainty, and Divergence of Opinion', Journal of Finance, Vol.32, pp. 1151-1168.

Mitchell, M, and E. Stafford (2000), 'Managerial Decisions and Long-Term Stock Price Performance', Journal of Business, Vol. 73, pp. 287-320.

Penman, S. H., and X. J. Zhang (2002), 'Accounting Conservatism, the Quality of Earnings and Stock Returns’, The Accounting Review, Vol. 77, pp. 237-264.

Rajan, R., and H. Servaes (1997), 'Analyst Following of Initial Public Offerings', Journal of Finance, Vol.52, pp. 507-529.

Ritter, J. (1991), 'The Long-run Performance of Initial Public Offerings', Journal of Finance, Vol. 46, pp. 3-27.

Ritter, J. (2003), 'Differences between European and American IPO Markets', European Financial Management, Vol. 9, pp. 421-434.

Ritter, J., and I. Welch (2002), 'A Review of IPO Activity, Pricing, and Allocations', Journal of Finance, Vol.57, pp. 1795-1828.

Rock, K. (1986), 'Why New Issues are Underpriced', Journal of Financial Economics, Vol.14, pp. 187-212.

Sloan, R. (1996), 'Do Stock Prices Fully Reflect Information in Accruals and Cash Flows about Future Earnings?’, The Accounting Review, Vol. 71, pp. 289-315.

Schrand, C., and R. E. Verrecchia (2004), 'Disclosure Choice and Cost of Capital: Evidence from Underpricing in Initial Public Offerings’, Working paper (University of Pennsylvania).

Teoh, S., I. Welch and T. Wong (1998), 'Earnings Management and the Long-run Market Performance of Initial Public Offerings’, Journal of Finance, Vol. 53, pp. 1935-1974. 
Figure 1

\section{Cumulative Proceeds of Seasoned Equity Offerings by Sample IPO Portfolios Over Three Years After IPO, By Event Month}

The sample includes 2696 IPOs issued from 1980 to 1995 . Unit offerings, REITs, ADRs, F-1 filings, and filings of financial and services firms are excluded from the sample. In each sample year from 1980 to 1995, a median of R\&D expenditures relative to sales (R\&D_SALES) is computed for all the IPOs issued in the sample year with positive amounts of R\&D expenditures. Each of the IPOs issued in the sample year is then classified into a low- or high-R\&D portfolio depending on whether its RD_SALES is below or above the median of R\&D_Sales. IPOs with no $R \& D$ expenditures are assigned to a No-R\&D portfolio. The graph depicts the cumulative proceeds of seasoned equity offerings over three years after the IPO normalized by the IPO proceeds for each of the three R\&D portfolios. Nominal proceeds are converted to the 1995 real dollars using the CPI. The horizontal axis is event month with month 0 representing the IPO month.

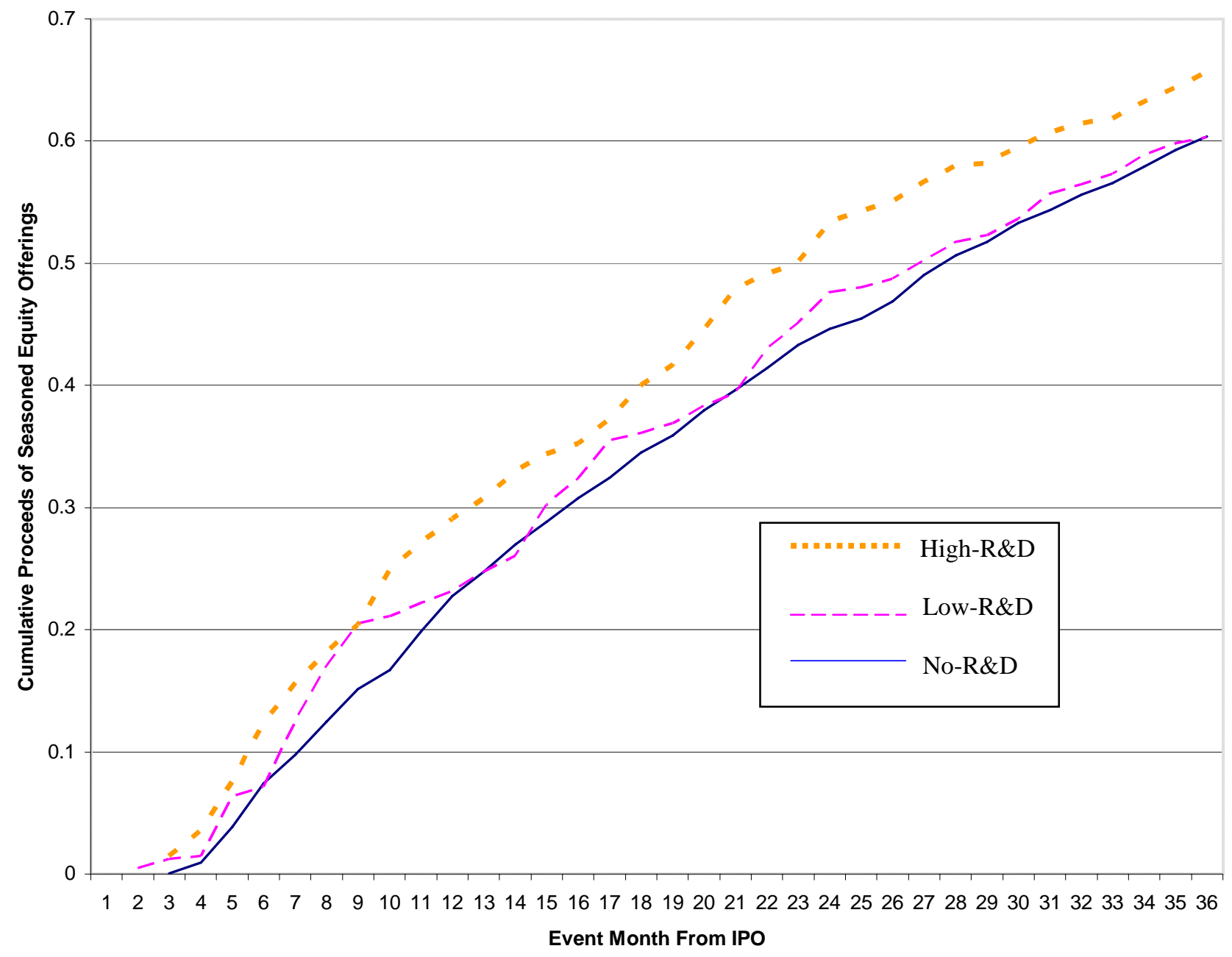


Table 1

Sample Selection Criteria

Sample Selection Step

No. Firms

Total number of firm commitment domestic IPOs

issued during 1980-1995, excluding unit offers

6010

Less: financials (SIC, 6000-7000) and service firms (SIC, >8100)

Less: IPOs with offer price under \$3 per share

Less: IPOs with no required price data from SDC or CRSP

to compute initial underpricing or subsequent returns

Less: observations lacking required Compustat accounting variables

Less: observations lacking values for underwriter reputation measure or primary shares offered

Subtotal: $\quad 3838$

Subtotal: $\quad \frac{(908)}{2930}$

Subtotal: $\frac{(150)}{2780}$

Less: observations that reported zero sales

Less: observations with extreme values of initial underpricing

(below 0.5th and exceeding 99.5th percentiles)

Final sample $\quad 2696$ 
Table 2

\section{Descriptive Statistics of IPO Samples and Selected Variables for Portfolios Classified by R\&D Expenditures to Sales}

The sample includes 2696 IPOs issued from 1980 to 1995. Unit offerings, REITs, ADRs, F-1 filings, and filings of financial and services firms are excluded from the sample. In each sample year from 1980 to 1995, a median of R\&D expenditures relative to sales (R\&D_SALES) is computed for all the IPOs issued in the sample year with positive amounts of R\&D expenditures. Each of the IPOs issued in the sample year is then classified into a low- or high-R\&D portfolio depending on whether its RD_SALES is below or above the median of R\&D_Sales. IPOs with no R\&D expenditures are assigned to a No-R\&D portfolio. R\&D_EXPMV is R\&D expenditures relative to expected market value after IPO, where the expected market value is the product of the midpoint of the offer price range and the total expected number of shares outstanding upon the IPO. R\&D expenditures and sales are those reported in the last fiscal year prior to the IPO. PROCEEDS is the gross proceeds from the offering. SALES is annual sale revenues. PROCEEDS, and SALES are measured in millions of dollars and inflation adjusted to the 1995 price level using CPI index. SECOND is the proportion of the total shares offered by current shareholders. CM is an updated Carter-Manaster discrete underwriter reputation measure 0-9 where a 9 (0) is the most (least) prestigious underwriter. P_AJT is the percentage change from the mid point of the offer price range to the offer price. VC is dummy variable taking the value of one if an issue has venture capital backing and value of zero otherwise. INSIDE is the proportion of total shares outstanding retained by insiders after the IPO.

\section{Panel A: Distribution of Sample IPOs and IPOs with Positive R\&D by Year}

\begin{tabular}{|c|c|c|c|}
\hline Year & $\begin{array}{r}\text { Sample } \\
\text { IPOs }\end{array}$ & $\begin{array}{r}\text { With } \\
\text { Positive } \\
\text { R\&D (\#) }\end{array}$ & $\begin{array}{r}\text { With } \\
\text { Positive } \\
\text { R\&D (\%) }\end{array}$ \\
\hline 1980 & 33 & 21 & 64 \\
\hline 1981 & 97 & 52 & 54 \\
\hline 1982 & 36 & 21 & 58 \\
\hline 1983 & 229 & 129 & 56 \\
\hline 1984 & 107 & 47 & 44 \\
\hline 1985 & 95 & 42 & 44 \\
\hline 1986 & 236 & 101 & 43 \\
\hline 1987 & 185 & 77 & 42 \\
\hline 1988 & 70 & 29 & 41 \\
\hline 1989 & 67 & 28 & 42 \\
\hline 1990 & 77 & 38 & 49 \\
\hline 1991 & 202 & 98 & 49 \\
\hline 1992 & 285 & 129 & 45 \\
\hline 1993 & 363 & 144 & 40 \\
\hline 1994 & 299 & 122 & 41 \\
\hline 1995 & 315 & 180 & 57 \\
\hline Total & 2696 & 1257 & 47 \\
\hline
\end{tabular}


Panel B: Distribution of Sample IPOs and IPOs with Positive R\&D by Industry

\begin{tabular}{|c|c|c|c|}
\hline Industry & $\begin{array}{c}\text { Total } \\
\text { IPOs (\#) }\end{array}$ & $\begin{array}{c}\text { With } \\
\text { Positive } \\
\text { R\&D (\#) }\end{array}$ & $\begin{array}{c}\text { With } \\
\text { Positive } \\
\text { R\&D (\%) }\end{array}$ \\
\hline Computer Hardware and Software & 618 & 484 & 78 \\
\hline Electronic Equipment & 296 & 261 & 88 \\
\hline Paper and Paper Products & 82 & 18 & 22 \\
\hline Chemical Products & 155 & 130 & 84 \\
\hline Communications & 99 & 11 & 11 \\
\hline Durable Goods & 106 & 18 & 17 \\
\hline Eating and Drinking Establishments & 74 & 2 & 3 \\
\hline Electric and Gas Services & 50 & 5 & 10 \\
\hline Entertainment Services & 65 & 2 & 3 \\
\hline Food Products & 47 & 9 & 19 \\
\hline Health & 127 & 8 & 6 \\
\hline Manufacturing & 130 & 48 & 37 \\
\hline Oil and Gas & 56 & 6 & 11 \\
\hline Retail & 205 & 4 & 2 \\
\hline Scientific Instruments & 195 & 184 & 94 \\
\hline Transportation & 175 & 52 & 30 \\
\hline All Others & 216 & 15 & 7 \\
\hline Total & 2696 & 1257 & 47 \\
\hline
\end{tabular}


Panel C: Descriptive Statistics of Selected Variables for Portfolios Classified by R\&D to Sales

\begin{tabular}{|c|c|c|c|c|c|c|c|c|}
\hline \multirow[b]{2}{*}{ Variable } & \multicolumn{4}{|c|}{ Mean } & \multicolumn{4}{|c|}{ Median } \\
\hline & $\begin{array}{c}\begin{array}{c}\text { Full } \\
\text { Sample }\end{array} \\
\end{array}$ & $\underline{\text { No-R\&D }}$ & Low-R\&D & High-R\&D & $\begin{array}{c}\begin{array}{c}\text { Full } \\
\text { Sample }\end{array} \\
\end{array}$ & $\underline{\text { No-R\&D }}$ & Low-R\&D & $\underline{\text { High-R \&D }}$ \\
\hline RD_SALES & 0.49 & 0.00 & 0.04 & 2.06 & 0.00 & 0.00 & 0.03 & 0.20 \\
\hline R\&D_EXPMV & 0.02 & 0.00 & 0.02 & 0.05 & 0.00 & 0.00 & 0.02 & 0.04 \\
\hline PROCEEDS & 40.63 & 45.38 & 41.95 & 28.55 & 23.78 & 24.19 & 23.32 & 23.40 \\
\hline EXPMV & 245.95 & 346.38 & 166.97 & 95.33 & 69.09 & 68.44 & 67.01 & 74.22 \\
\hline SALES & 153.75 & 194.84 & 188.87 & 25.71 & 34.53 & 54.65 & 36.42 & 12.14 \\
\hline SECOND & 0.16 & 0.14 & 0.21 & 0.15 & 0.07 & 0.00 & 0.19 & 0.07 \\
\hline $\mathrm{CM}$ & 6.79 & 6.71 & 6.84 & 6.90 & 8.74 & 8.50 & 8.50 & 8.75 \\
\hline P_AJT & 0.43 & -1.62 & 1.31 & 4.21 & 0.00 & 0.00 & 0.00 & 0.00 \\
\hline $\mathrm{VC}$ & 0.42 & 0.26 & 0.44 & 0.75 & 0.00 & 0.00 & 0.00 & 1.00 \\
\hline INSIDE & 0.67 & 0.66 & 0.65 & 0.70 & 0.70 & 0.68 & 0.69 & 0.73 \\
\hline No. of Obs. & 2696 & 1439 & 624 & 633 & 2696 & 1439 & 624 & 633 \\
\hline
\end{tabular}


Table 3

\section{Average First-Day IPO Return for R\&D Portfolios Using Alternative Benchmarks and Sample Partitions}

The sample includes 2696 IPOs issued from 1980 to 1995. Unit offerings, REITs, ADRs, F-1 filings, and filings of financial and services firms are excluded from the sample. In each sample year from 1980 to 1995, a median of R\&D expenditures relative to sales (R\&D_SALES) is computed for all the IPOs issued in the sample year with positive amounts of R\&D expenditures. Each of the IPOs issued in the sample year is then classified into a low- or high-R\&D portfolio depending on whether its RD_SALES is below or above the median of R\&D_Sales. IPOs with no R\&D expenditures are assigned to a No-R\&D portfolio. R\&D expenditures and sales are those reported in the last fiscal year prior to IPO. The market-adjusted initial return is the percentage change from the offer price to the first available closing price, subtracted by the contemporaneous NYSE/AMEX/NASDAQ value-weighted market index return except when noted otherwise in Panel A. The sample partition using underwriter reputation is based on the sample median of the underwriter reputation measure, CM, where CM is an updated Carter-Manaster discrete underwriter reputation measure 0-9 where a 9 (0) is the most (least) prestigious underwriter.

\begin{tabular}{|c|c|c|c|c|}
\hline & Full Sample & No-R\&D & Low-R\&D & High-R\&D \\
\hline \multicolumn{5}{|c|}{ Panel A: Benchmark Variations } \\
\hline \multicolumn{5}{|l|}{$\underline{\text { Initial Return }}$} \\
\hline Raw Returns & 10.8 & 8.78 & 11.17 & 15.04 \\
\hline Market Adj., value weight & 10.76 & 8.74 & 11.13 & 14.99 \\
\hline Market Adj., equal weight & 10.74 & 8.73 & 11.09 & 14.96 \\
\hline
\end{tabular}

Panel B: Value-Weighted Market-Adjusted Return, Partitioned by Sample Period

\begin{tabular}{lcccc}
\hline Sample Period & & & & \\
$1980-1983$ & 11.46 & 10.20 & 11.45 & 13.37 \\
$1984-1989$ & 5.86 & 4.72 & 7.36 & 7.42 \\
$1990-1995$ & 13.01 & 10.55 & 12.74 & 19.00 \\
\hline
\end{tabular}

Panel C: Value-Weighted Market-Adjusted Return, Partitioned by IPO Issue Proceeds

\begin{tabular}{|c|c|c|c|c|}
\hline \multicolumn{5}{|l|}{ Proceeds } \\
\hline$\overline{\text { Small (1 }} 1^{\text {st }}$ quartile) & 9.52 & 8.82 & 10.53 & 10.18 \\
\hline Medium ( $2^{\text {nd }} \& 3^{\text {rd }}$ quartiles $)$ & 11.3 & 9.13 & 11.46 & 14.78 \\
\hline Large ( $4^{\text {th }}$ quartile) & 10.94 & 8.04 & 11.15 & 22.66 \\
\hline
\end{tabular}

Panel D: Value-Weighted Market-Adjusted Return Partitioned by Underwriter Reputation

$\underline{\text { Reputation }}$

High Reputation

Low Reputation

Panel E: Value-Weighted Market-Adjusted Return Partitioned by Venture Capital Backing

Venture Capital

VC Backing

12.56

No VC Backing

9.47

11.25

10.27

8.03

9.41

11.94

10.34

16.98

12.49 
Table 4

\section{Cross-Sectional Regressions of First-Day IPO Return on R\&D Portfolio Dummies, Controlling for Time-Series Variation and Other Underpricing Determinants}

The dependent variable is the market-adjusted initial return of a sample of 2696 IPOs issued from 1980 to 1995. Unit offerings, REITs, ADRs, F-1 filings, and filings of financial and services firms are excluded from the sample. The marketadjusted initial return is the percentage change from the offer price to the first available closing price, subtracted by the contemporaneous NYSE/AMEX/NASDAQ value-weighted market index return. The sample is classified into Non-, Low-, and High-R\&D portfolios using alternative R\&D intensity measures, R\&D expenditures relative to sales (R\&D_SALES) and R\&D expenditures relative to expected market value after IPO (R\&D_EXPMV), respectively. E.g., consider the case of R\&D_SALES. In each sample year from 1980 to 1995, a median of R\&D_SALES is computed for all the IPOs issued in the sample year with positive amounts of R\&D expenditures. Each of the IPOs issued in the same sample year is then classified into a low- or high-R\&D portfolio depending on whether its RD_SALES is below or above the median of R\&D_Sales. IPOs with no R\&D expenditures are assigned to a No-R\&D portfolio. R\&D expenditures and sales are those reported in the last fiscal year prior to the IPO. D1, D2, D3 for Panel A below are the portfolio classification dummies taking the value of one if an IPO belongs to No-R\&D, Low-R\&D, or High-R\&D portfolio and zero otherwise. In Panel B, continuous R\&D intensity measures are used in place of R\&D dummies, where LOGRD_SALES (LOGRD_EXPMV) is the natural logarithm of 1 plus R\&D_SALES*100 (R\&D_SALES*100).

Control variables for Panel A and B are as follows. LPROCEEDS is the natural logarithm of the gross proceeds from the offering, measured in millions of dollars and inflation adjusted to the 1995 price level using CPI index. P_AJT is the percentage change from the mid point of the offer price range to the offer price. CM is an updated Carter-Manaster discrete underwriter reputation measure $0-9$ where a $9(0)$ is the most (least) prestigious underwriter. SECOND is the proportion of the total shares offered by current shareholders. INSIDE is the proportion of total shares outstanding retained by insiders after the IPO. VC is dummy variable taking value of one if an issue has venture capital backing and the value of zero otherwise. Each regression model also includes subperiod (80-83, 84-89, 90-95) dummies whose coefficients are not tabulated. One and two asterisks indicate the significance at the 5 and 1 percent levels, respectively.

\section{Panel A: Cross-Sectional Regression of First-Day IPO Return on R\&D Portfolio Dummies}

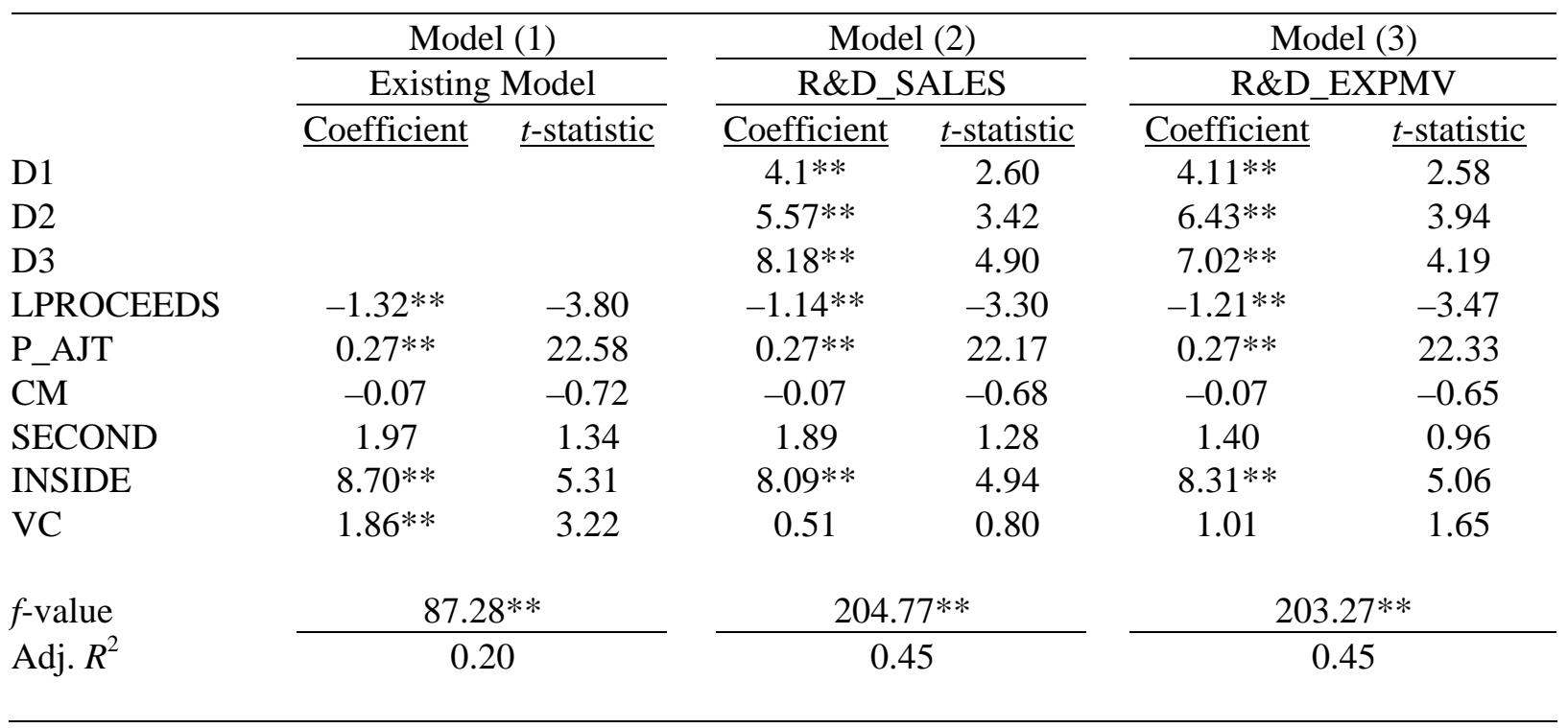

F Tests of Pair-Wise Comparisons of R\&D Portfolio Dummies

\begin{tabular}{|c|c|c|c|}
\hline Model & D2-D1 & D3-D2 & D3-D1 \\
\hline Model (2) & $1.47^{*}$ & $2.61^{* *}$ & $4.08 * *$ \\
\hline Model (3) & $2.32^{* *}$ & 0.59 & $2.81^{* *}$ \\
\hline
\end{tabular}


Panel B: Cross-Sectional Regression of First-Day IPO Return on Continuous R\&D Intensity Measures

\begin{tabular}{|c|c|c|c|c|}
\hline & \multirow{2}{*}{\multicolumn{2}{|c|}{$\begin{array}{c}\text { Model (2) } \\
\text { R\&D_SALES }\end{array}$}} & \multirow{2}{*}{\multicolumn{2}{|c|}{$\begin{array}{c}\text { Model (3) } \\
\text { R\&D_EXPMV }\end{array}$}} \\
\hline & & & & \\
\hline & Coefficient & $\underline{t \text {-statistic }}$ & Coefficient & $\underline{t \text {-statistic }}$ \\
\hline LOGRD_SALES & $0.93 * *$ & 4.95 & & \\
\hline LOGRD_EXPMV & & & $0.85 *$ & 2.19 \\
\hline LPROCEEDS & $-1.16^{* *}$ & -3.34 & $-1.24 * *$ & -3.55 \\
\hline P_AJT & $0.27 * *$ & 22.44 & $0.27 * *$ & 22.15 \\
\hline $\mathrm{CM}$ & -0.07 & -0.65 & -0.08 & -0.77 \\
\hline SECOND & 2.31 & 1.58 & 1.79 & 1.22 \\
\hline INSIDE & $8.26^{* *}$ & 5.06 & $8.98 * *$ & 5.47 \\
\hline VC & 0.64 & 1.03 & $1.38 *$ & 2.24 \\
\hline$f$-value & 224. & $* *$ & & \\
\hline Adj. $R^{2}$ & 0. & & & \\
\hline
\end{tabular}


Table 5

\section{Cross-Sectional Regressions of First-Day IPO Return on the Change in R\&D Intensity, Controlling for Time-Series Variation and Other Underpricing Determinants}

The dependent variable is the market-adjusted initial return of a sample of 2696 IPOs issued from 1980 to 1995. Unit offerings, REITs, ADRs, F-1 filings, and filings of financial and services firms are excluded from the sample. The market-adjusted initial return is the percentage change from the offer price to the first available closing price, subtracted by the contemporaneous NYSE/AMEX/NASDAQ value-weighted market index return. The sample is classified into Non-, Low-, and High-R\&D portfolios using the change in R\&D intensity measures, R\&D expenditures relative to sales (R\&D_SALES) and R\&D expenditures relative to expected market value after the IPO (R\&D_EXPMV), respectively. E.g., consider the case of the change in R\&D_SALES, which is computed as the difference between R\&D expenditures in the fiscal year immediately after IPO to those prior to IPO, normalized by pre-IPO annual sales. In each sample year from 1980 to 1995, a median of the change in R\&D_SALES is computed for all the IPOs issued in the same sample year with positive amounts of R\&D expenditures. An IPOs issued in the same sample year with a positive amount of R\&D is then classified into a low- or high-R\&D portfolio depending on whether its change in RD_SALES is below or above the median of the change in R\&D_Sales. IPOs with no R\&D expenditures are assigned to a No-R\&D portfolio. D1, D2, D3 are the portfolio classification dummies taking the value of one if an IPO belongs to No-R\&D, LowR\&D, or High-R\&D portfolio and zero otherwise. LPROCEEDS is the natural logarithm of the gross proceeds from the offering, measured in millions of dollars and inflation adjusted to the 1995 price level using CPI index. P_AJT is the percentage change from the mid point of the offer price range to the offer price. CM is an updated Carter-Manaster discrete underwriter reputation measure 0-9 where a 9 (0) is the most (least) prestigious underwriter. SECOND is the proportion of the total shares offered by current shareholders. INSIDE is the proportion of total shares outstanding retained by insiders after the IPO. VC is dummy variable taking value of one if an issue has venture capital backing and the value of zero otherwise. Each regression model also includes subperiod (80-83, 84-89, 90-95) dummies whose coefficients are not tabulated. One and two asterisks indicate the significance at the 5 and 1 percent levels, respectively.

\begin{tabular}{|c|c|c|c|c|}
\hline & \multicolumn{2}{|c|}{ Change in R\&D_SALES } & \multicolumn{2}{|c|}{ Change in R\&D_EXPMV } \\
\hline & Coefficient & $\underline{t \text {-statistic }}$ & $\underline{\text { Coefficient }}$ & $\underline{t \text {-statistic }}$ \\
\hline D1 & $4.02 * *$ & 2.54 & $3.47 * *$ & 2.20 \\
\hline D2 & $5.85 * *$ & 3.62 & $3.78 * *$ & 2.28 \\
\hline D3 & $9.35 * *$ & 5.31 & $8.85^{* *}$ & 5.43 \\
\hline LPROCEEDS & $-1.25 * *$ & -3.58 & $-1.11^{* *}$ & -3.20 \\
\hline P_AJT & $0.27 * *$ & 22.35 & $0.27 * *$ & 21.94 \\
\hline$\overline{\mathrm{CM}}$ & -0.06 & -0.60 & -0.10 & -0.99 \\
\hline SECOND & 2.32 & 1.56 & 1.93 & 1.33 \\
\hline INSIDE & $8.27 * *$ & 5.07 & $9.23^{* *}$ & 5.67 \\
\hline VC & 0.54 & 0.87 & 0.31 & 0.50 \\
\hline$f$-value & \multicolumn{2}{|c|}{$205.05^{* *}$} & \multicolumn{2}{|c|}{$209.50 * *$} \\
\hline Adj. $R^{2}$ & \multicolumn{2}{|c|}{0.45} & \multicolumn{2}{|c|}{0.46} \\
\hline
\end{tabular}

F Tests of Pair-Wise Comparisons of R\&D Portfolio Dummies

\begin{tabular}{|c|c|c|c|}
\hline Model & D2-D1 & D3-D2 & D3-D1 \\
\hline Change in R\&D_SALES & $1.83^{* *}$ & $3.50 * *$ & $5.33^{* *}$ \\
\hline Change in R\&D_EXPMV & 0.31 & $5.07 * *$ & $5.38 * *$ \\
\hline
\end{tabular}


Table 6

Cross-Sectional Regressions of First-Day IPO Return on R\&D Dummies and the Interaction between the Pharmaceutical and Biotech Industries and High-R\&D Portfolio

The dependent variable is the market-adjusted initial return of a sample of 2696 IPOs issued from 1980 to 1995. Unit offerings, REITs, ADRs, F-1 filings, and filings of financial and services firms are excluded from the sample. The market-adjusted initial return is the percentage change from the offer price to the first available closing price, subtracted by the contemporaneous NYSE/AMEX/NASDAQ value-weighted market index return. The sample is classified into Non-, Low-, and High-R\&D portfolios using R\&D expenditures relative to sales (R\&D_SALES). In each sample year from 1980 to 1995, a median of R\&D_SALES is computed for all the IPOs issued in the sample year with positive amounts of R\&D expenditures. Each of the IPOs issued in the same sample year is then classified into a low- or high-R\&D portfolio depending on whether its RD_SALES is below or above the median of R\&D_Sales. IPOs with no R\&D expenditures are assigned to a No-R\&D portfolio. R\&D expenditures and sales are those reported in the last fiscal year prior to IPO. D1, D2, D3 are the portfolio classification dummies taking the value of one if an IPO belongs to No-R\&D, Low-R\&D, or High-R\&D portfolio and zero otherwise. DRUG is a dummy set equal to one if an IPO is in drugs and pharmaceutical industry (sic=283) and zero otherwise. LPROCEEDS is the natural logarithm of the gross proceeds from the offering, measured in millions of dollars and inflation adjusted to the 1995 price level using CPI index. P_AJT is the percentage change from the mid point of the offer price range to the offer price. CM is an updated CarterManaster discrete underwriter reputation measure 0-9 where a $9(0)$ is the most (least) prestigious underwriter. SECOND is the proportion of the total shares offered by current shareholders. INSIDE is the proportion of total shares outstanding retained by insiders after the IPO. VC is dummy variable taking value of one if an issue has venture capital backing and the value of zero otherwise. Regression model also includes subperiod (80-83, 8489, 90-95) dummies whose coefficients are not tabulated. One and two asterisks indicate the significance at the 5 and 1 percent levels, respectively.

\begin{tabular}{|c|c|c|}
\hline & Coefficient & $\underline{t \text {-statistic }}$ \\
\hline D1 & $4.14 * *$ & 2.62 \\
\hline D2 & $5.65^{* *}$ & 3.46 \\
\hline D3 & $9.04 * *$ & 5.35 \\
\hline DRUG*D3 & $-5.64 * *$ & -3.46 \\
\hline LPROCEEDS & $-1.13 * *$ & -3.24 \\
\hline P_AJT & $0.26 * *$ & 21.82 \\
\hline CM & -0.07 & -0.68 \\
\hline SECOND & 1.34 & 0.91 \\
\hline INSIDE & $8.12^{* *}$ & 4.97 \\
\hline VC & 0.56 & 0.90 \\
\hline$f$-value & \multicolumn{2}{|c|}{$189.48 * *$} \\
\hline Adj. $R^{2}$ & \multicolumn{2}{|c|}{0.45} \\
\hline
\end{tabular}


Table 7

Four-Factor Time-Series Regressions of Monthly Returns on Portfolios of No-, Low-, and High- R\&D Intensity

In each sample year from 1980 to 1995, a median of R\&D_SALES/R\&D_EXPMV is computed for all the IPOs issued in the same sample year with positive amounts of R\&D expenditures. An IPOs issued in the same sample year with a positive amount of $R \& D$ is then classified into a low- or high-R\&D portfolio when its RD_SALES/R\&D_EXPMV is below or above the median of the R\&D intensity measure. IPOs with no R\&D expenditures are assigned to a No-R\&D portfolio. Panel A presents regression results on portfolios with zero, low and high ratio of R\&D_SALES. Panel B presents results of portfolios with zero, low and high ratio of R\&D_EXPMV. $R_{p t}$ is the equally-weighted returns of the portfolio of IPO firms in calendar month $t . R_{m t}$ is the return on the value-weighted index of NYSE, Amex, and Nasdaq stock in month $t ; \mathrm{R}_{\mathrm{ft}}$ is the beginning-of-month three month T-bill yield in month $t$; $\mathrm{SMB}_{\mathrm{t}}$ is the return on small firms minus the return on large firms in month $t$, $\mathrm{HML}_{\mathrm{t}}$ is the return on high book-to-market stocks minus the return on low book-to-market stocks in month $t$ (see Fama and French, 1993). PR12 is formed by taking the return on high momentum stocks minus the return on low momentum stocks. Returns of IPO firms are included in the portfolio returns only for the period from the $7^{\text {th }}$ till the $42^{\text {nd }}$ months subsequent to the offerings for the period of April 1981 to December 1998. Parameter estimates are shown in the table with the corresponding t-statistics in parenthesis. Each regression uses 213 monthly observations. One and two asterisks indicate the significance at the 5 and 1 percent levels, respectively.

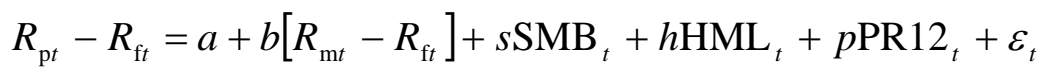

Panel A: Regression Analysis on Portfolios Sorted by Ratio of R\&D_SALES

\begin{tabular}{lllllll}
\hline \multicolumn{7}{c}{ Coefficient Estimates } \\
\hline Full Sample & $a$ & $b$ & $s$ & $h$ & $p$ & $R_{\mathrm{adj}}{ }^{2}$ \\
& -0.21 & $1.08^{* *}$ & $1.17^{* *}$ & $-0.40^{* *}$ & $-0.20^{* *}$ & $90.63 \%$ \\
No-R\&D & $(-1.30)$ & $(27.36)$ & $(19.05)$ & $(-5.68)$ & $(-3.80)$ & \\
& $-0.50^{* *}$ & $1.05^{* *}$ & $1.07^{* *}$ & -0.10 & $-0.20^{* *}$ & $87.65 \%$ \\
Low-R\&D & $(-3.01)$ & $(25.64)$ & $(16.75)$ & $(-1.38)$ & $(-3.75)$ & \\
& 0.00 & $1.09^{* *}$ & $1.23^{* *}$ & $-0.44^{* *}$ & $-0.18^{* *}$ & $83.97 \%$ \\
High-R\&D & $(0.07)$ & $(19.71)$ & $(14.26)$ & $(-4.48)$ & $(-2.56)$ & \\
& 0.27 & $1.14^{* *}$ & $1.34^{* *}$ & $-0.90^{* *}$ & $-0.20^{*}$ & $83.31 \%$ \\
\hline
\end{tabular}

Panel B: Regression Analysis on Portfolios Sorted by Ratio of R\&D_EXPMV

\begin{tabular}{lllllll} 
& $a$ & $b$ & $s$ & $h$ & $p$ & $R_{\mathrm{adj}}^{2}$ \\
\hline Full Sample & -0.21 & $1.08^{* *}$ & $1.17^{* *}$ & $-0.40^{* *}$ & $-0.20^{* *}$ & $90.63 \%$ \\
& $(-1.30)$ & $(27.36)$ & $(19.05)$ & $(-5.68)$ & $(-3.80)$ & \\
No-R\&D & $-0.50^{* *}$ & $1.05^{* *}$ & $1.07^{* *}$ & -0.10 & $-0.20^{* *}$ & $87.65 \%$ \\
& $(-3.01)$ & $(25.64)$ & $(16.75)$ & $(-1.38)$ & $(-3.75)$ & \\
Low-R\&D & -0.00 & $1.08^{* *}$ & $1.17^{* *}$ & $-0.70^{* *}$ & -0.15 & $83.49 \%$ \\
& $(-0.02)$ & $(18.34)$ & $(12.70)$ & $(-6.68)$ & $(-1.88)$ & \\
High-R\&D & 0.27 & $1.13^{* *}$ & $1.38^{* *}$ & $-0.65^{* *}$ & $-0.22^{* *}$ & $83.09 \%$ \\
& $(1.04)$ & $(17.81)$ & $(13.94)$ & $(-5.78)$ & $(-2.67)$ & \\
\hline
\end{tabular}




\section{Table 8}

\section{Four-Factor Time-series Regression of Monthly Returns on Zero-Investment Portfolios of IPO Firms Classified by R\&D Intensity}

In each sample year from 1980 to 1995, a median of R\&D_SALES/R\&D_EXPMV is computed for all the IPOs issued in the same sample year with positive amounts of R\&D expenditures. An IPOs issued in the same sample year with a positive amount of $R \& D$ is then classified into a low- or high-R\&D portfolio when its RD_SALES/R\&D_EXPMV is below or above the median of the R\&D intensity measure. IPOs with no R\&D expenditures are assigned to a No-R\&D portfolio. Zero-investment portfolio is formed by longing certain group(s) of IPOs, while shorting certain group(s) of IPO firms, re-balanced monthly. Panel A presents regression results on portfolios with zero, low and high ratio of R\&D_SALES. Panel B presents results of portfolios with zero, low and high ratio of R\&D_EXPMV. $\mathrm{R}_{\mathrm{pt}}$ is the equally-weighted returns of the portfolio of IPO firms in calendar month $t . \mathrm{R}_{\mathrm{mt}}$ is the return on the value-weighted index of NYSE, Amex, and Nasdaq stock in month $t ; \mathrm{R}_{\mathrm{ft}}$ is the beginning-of-month three month T-bill yield in month $t ; \mathrm{SMB}_{\mathrm{t}}$ is the return on small firms minus the return on large firms in month $t, \mathrm{HML}_{\mathrm{t}}$ is the return on high book-to-market stocks minus the return on low book-to-market stocks in month $t$ (see Fama and French, 1993). PR12 is formed by taking the return on high momentum stocks minus the return on low momentum stocks. Returns of IPO firms are included in the portfolio returns only for the period from the $7^{\text {th }}$ till the $42^{\text {nd }}$ months subsequent to the offerings for the period of April 1981 to December 1998. Parameter estimates are shown in the table with the corresponding tstatistics in parenthesis. Each regression uses 213 monthly observations. One and two asterisks indicate the significance at the 5 and 1 percent levels, respectively.

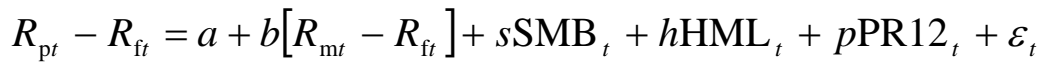

Panel A: Portfolios Sorted by Ratio of R\&D_SALES

\begin{tabular}{cccccccc}
\hline \multicolumn{7}{c}{ Coefficient Estimates } \\
\hline & $a$ & $b$ & $s$ & $h$ & $p$ & $R_{\mathrm{adj}}{ }^{2}$ \\
\hline Long high-R\&D group; short no- & $0.76^{* *}$ & 0.08 & $0.26^{*}$ & $-0.80^{* *}$ & 0.00 & $30.22 \%$ \\
R\&D group & $(2.68)$ & $(1.19)$ & $(2.40)$ & $(-6.40)$ & $(0.02)$ & \\
Long (high- and low-) R\&D & $0.64^{* *}$ & 0.06 & $0.21^{*}$ & $-0.58^{* *}$ & 0.01 & $25.72 \%$ \\
groups; short no-R\&D group & $(2.76)$ & $(1.05)$ & $(2.36)$ & $(-5.69)$ & $(0.12)$ & \\
\hline
\end{tabular}

Panel B: Portfolios Sorted by Ratio of R\&D_EXPMV

\begin{tabular}{ccccccc} 
& $a$ & $b$ & $s$ & $h$ & $p$ & $R_{\mathrm{adj}}^{2}$ \\
\hline Long high-R\&D group; short no- & $0.77^{* *}$ & 0.08 & $0.31^{* *}$ & $-0.55^{* *}$ & -0.02 & $22.07 \%$ \\
R\&D group & $(2.82)$ & $(1.17)$ & $(2,95)$ & $(-4.62)$ & $(-0.23)$ & \\
Long (high- and low-) R\&D & $0.64^{* *}$ & 0.0 & $0.21^{*}$ & $-0.58^{* *}$ & 0.01 & $25.72 \%$ \\
groups; short no-R\&D group & $(2.76)$ & $(1.05)$ & $(2.36)$ & $(-5.69)$ & $(0.12)$ & \\
\hline
\end{tabular}


Table 9

Mean Parameter Values from Monthly Cross-Sectional Regressions of Stock Returns on R\&D Intensity, Size, Book-to-Market, and New Issue Variables

The sample consists over the period from April 1981 to December 1998 of the universe of New York Stock Exchange (NYSE), American Stock Exchange (AMEX), and Nasdaq firms for which the book value of equity is available from COMPUSTAT and monthly returns data is available from CRSP. In each month, returns for all firms with appropriate data are regressed on the firm's own size, book-to-market ratio, the three R\&D dummy variables (D1, D2, and D3) for no-, low-, and high- R\&D IPOs; an underwriter reputation measure (CM); and a VC-backing indicator. MV and BV/MV are the market value (in millions) of equity, and the ratio of the book value of equity to the market value of equity at the prior yearend. ISSUE is the binary variable with value of one for IPO firms, and zero otherwise. An issue is considered as IPO when it falls in the period from the $3^{\text {rd }}$ to 38th month after the IPO. CM is an updated Carter-Manaster discrete underwriter reputation measure with a value of 9 (0) for the most (least) prestigious underwriter (Carter and Manaster, 1990). VC is dummy variable taking the value of one if an issue has venture capital backing and value of zero otherwise. The average parameter values over 213 monthly regressions are presented, with the $t$ statistics (in parenthesis) and the percentage of the coefficient estimates that are positive (in brackets). One, two and three asterisks indicate the significance at the 10, 5, and 1 percent levels, respectively.

\begin{tabular}{|c|c|c|c|c|}
\hline & \multicolumn{2}{|c|}{$\begin{array}{c}\text { Portfolios Sorted by Ratio of } \\
\text { R\&D_SALES }\end{array}$} & \multicolumn{2}{|c|}{$\begin{array}{c}\text { Portfolios Sorted by Ratio of } \\
\text { R\&D_EXPMV }\end{array}$} \\
\hline & Model 1 & Model 2 & Model 3 & Model 4 \\
\hline \multirow[t]{3}{*}{ Intercept } & $1.56 * * *$ & $1.56 * * *$ & $1.56 * * *$ & $1.56 * * *$ \\
\hline & $(3.48)$ & $(3.47)$ & $(3.49)$ & $(3.47)$ \\
\hline & [0.57] & [0.57] & [0.57] & [0.58] \\
\hline \multirow[t]{3}{*}{$\ln (\mathrm{MV})$} & -0.04 & -0.04 & -0.03 & -0.04 \\
\hline & $(-0.64)$ & $(-0.63)$ & $(-0.64)$ & $(-0.64)$ \\
\hline & [0.49] & {$[0.48]$} & [0.49] & {$[0.48]$} \\
\hline \multirow[t]{3}{*}{$\ln (\mathrm{BV} / \mathrm{MV})$} & $0.44 * * *$ & $0.43 * * *$ & $0.43 * * *$ & $0.43 * * *$ \\
\hline & $(6.45)$ & $(6.44)$ & $(6.43)$ & (6.41) \\
\hline & {$[0.66]$} & {$[0.66]$} & {$[0.65]$} & {$[0.66]$} \\
\hline \multirow[t]{3}{*}{ D1*ISSUE } & $-1.11^{* * *}$ & $-1.16 * * *$ & $-1.08 * * *$ & $-1.12 * * *$ \\
\hline & $(-3.88)$ & $(-3.98)$ & $(-3.80)$ & $(-3.85)$ \\
\hline & {$[0.38]$} & [0.39] & {$[0.36]$} & {$[0.38]$} \\
\hline \multirow[t]{3}{*}{ D2*ISSUE } & $-0.66 * *$ & $-0.70 * *$ & $-0.62^{*}$ & $-0.61 *$ \\
\hline & $(-2.10)$ & $(-2.30)$ & $(-1.88)$ & $(-1.88)$ \\
\hline & {$[0.41]$} & {$[0.41]$} & {$[0.40]$} & {$[0.41]$} \\
\hline \multirow[t]{3}{*}{ D3*ISSUE } & -0.43 & -0.36 & -0.47 & -0.36 \\
\hline & $(-1.20)$ & $(-0.97)$ & $(-1.36)$ & $(-1.03)$ \\
\hline & {$[0.46]$} & {$[0.43]$} & {$[0.45]$} & {$[0.44]$} \\
\hline \multirow[t]{3}{*}{$\ln (1+\mathrm{CM}) * \mathrm{ISSUE}$} & $0.26^{* *}$ & $0.31 * * *$ & $0.23^{*}$ & $0.29 * *$ \\
\hline & $(2.12)$ & $(2.60)$ & (1.88) & (2.39) \\
\hline & {$[0.56]$} & {$[0.58]$} & {$[0.55]$} & {$[0.57]$} \\
\hline \multirow[t]{3}{*}{ VC*ISSUE } & 0.22 & - & 0.29 & - \\
\hline & (0.99) & & (1.30) & \\
\hline & [0.54] & & [0.51] & \\
\hline Adjusted $\mathrm{R}^{2}$ & $1.75 \%$ & $1.59 \%$ & $1.60 \%$ & $1.59 \%$ \\
\hline
\end{tabular}




\section{Table 10}

\section{IPO Investor Optimism and R\&D Intensity}

The sample includes 1153 IPOs issued during 1980-1995. To be included in the sample, an IPO must have longterm growth forecast of earnings and five years worth of historical earnings growth available from Institutional Brokers Estimate System (I/B/E/S). In Panel A, IPO investor optimism is measured as the difference between the consensus analyst forecast of long-term earnings growth made within one year after IPO and the five-year historical earnings growth (in percentage); the variable is winsorized at the top and bottom 0.5 percentiles. The sample is classified into no-, low-, and high-R\&D portfolios using alternative R\&D intensity measures, R\&D expenditures relative to sales (R\&D_SALES), and R\&D expenditures relative to expected market value of the IPO (R\&D_EXPMV), respectively. R\&D expenditures and sales are those reported in the last fiscal year prior to the IPO. In Panel B, the dependent variable is IPO investor optimism. D1, D2, D3 are the portfolio classification dummies as described in Table 9. LOGMVE is the natural logarithm of the market value of equity of the IPO, measured as the closing price (in millions of dollars) at the end of the first trading day and inflation adjusted to the 1995 price level using CPI index. Each regression model also includes subperiod (1980-1983, 1984-1989, 1990-1995) dummies, and one-digit industry dummies, although coefficients are not tabulated in the interest of brevity. One, two, and three asterisks indicate the significance at the 10, 5, and 1 percent levels, respectively.

\section{Panel A: Mean Investor Optimism by R\&D Portfolios}

\begin{tabular}{lccc}
\hline & $N$ & R\&D_SALES & R\&D_EXPMV \\
\hline No-R\&D & 615 & 12.13 & 12.13 \\
Low-R\&D & 275 & 11.09 & 9.33 \\
High-R\&D & 263 & 3.43 & 5.62 \\
& & & \\
(Low-R\&D) - (High-R\&D) & & $7.66^{* *}$ & 3.71 \\
(No-R\&D) - (High-R\&D) & & $8.70^{* * *}$ & $6.51^{* *}$ \\
\hline
\end{tabular}

Panel B: Cross-Sectional Regressions of IPO Investor Optimism on R\&D Portfolio Dummies, Controlling for Firm Size, Industry, and Time-Series Effects

\begin{tabular}{|c|c|c|c|c|}
\hline & \multicolumn{2}{|c|}{ R\&D_SALES } & \multicolumn{2}{|c|}{ R\&D_EXPMV } \\
\hline & Coefficient & t-statistic & Coefficient & t-statistic \\
\hline LOGMVE & $-2.44 * *$ & -2.15 & $-2.57 * *$ & -2.25 \\
\hline D1 & $42.73 * *$ & 2.08 & $43.31 * *$ & 2.10 \\
\hline D2 & $41.88 * *$ & 2.01 & $41.47 * *$ & 1.98 \\
\hline D3 & $35.08 *$ & 1.68 & $37.10 *$ & 1.78 \\
\hline$f$-value & $7.28 * * *$ & & $7.11 * * *$ & \\
\hline Adj. $R^{2}$ & 0.07 & & 0.06 & \\
\hline$N$ & 1153 & & 1153 & \\
\hline & & f-statistic & & f-statistic \\
\hline D2-D3 & $6.80 *$ & 3.51 & 4.37 & 1.48 \\
\hline D1-D3 & $7.65^{* *}$ & 4.23 & $6.21 *$ & 2.85 \\
\hline
\end{tabular}

